\title{
A comparative study about the Calculation of Primary energy factor (PEF) values of electricity generation for the policymaking in the Energy sector
}

\author{
Usman Rasheed 1,2, Syed Muhammad Anas Ibrahim ${ }^{3}$, Hyundong Lee 1,2*, \\ 1 Environment and Plant Engineering Research Institute, Korea Institute of Civil Engineering \\ and Building Technology (KICT), Daehwa-dong 315, Goyangdae-Ro, Ilsanseo-gu, Goyang-si, \\ Gyeonggi-do 10223, Korea \\ 2 Construction Environment Engineering, University of Science \& Technology (UST), 217, \\ Gajeong-ro, Yuseong-gu, Daejeon 34113, Korea \\ 3 Department of Optical Engineering, Sejong University Graduate School, 209 Neungdong-ro \\ Gwangjin_Gu, Seoul, South Korea 05006.
}

* Correspondence: hdlee@kict.re.kr ; Tel.: +82-10-2042-3351

\begin{abstract}
The stability between the limited available energy resources and their consumption is an important concern of the modern world. The study deals with the development of the methods for measuring the energy performance of different renewable and non-renewable resources used for electricity generation with the help of an energy performance indicator called the Primary Energy Factor (PEF). This study takes account of all energy stages from the resources extraction to its transportation, conversion, combustion and then finally to utilization. The study conducted a comparative approach to calculate the PEF values of electricity generated in South Korea from the period of 1980 to 2017. Four different methodologies namely Eurostat methodology, Life cycle methodology, Modified Eurostat methodology, and upper-end methodology have been used. A set of Programs has been written in MATLAB to calculate the

i. $\quad$ PEF values of electricity generated.

ii. Impact of different renewable and non-renewable energy sources on PEF values.

iii. $\quad$ Future trend of PEF values of electricity in South Korea.

At the national and local level, this study will help the government and other law-making institutions to make policies regarding annual purchase consumptions of energies by different industrial, residential, public and transportation sectors and at the Global level, the implementation of this study will be the catastrophe of maintaining the stability between the available energy resources, and consumptions. This, in turn, will lead to the suitable living conditions for future generations
\end{abstract}

Keywords: Primary energy factor (PEF); Energy Analysis of South Korea; Electricity analysis.

\section{Introduction}

The World population is about 7.5 billion and it will increase to around 13 billion in 2100 . [1,2]. The earth resources are continuously decreasing and there is no visible way to sustain the earth's resources. The planet earth has already lost its stability in different shapes and spheres and it's not possible to reset it 
[3]. The humanity should maintain the stability between natural resources and its utilization to provide a stable living condition for future generations [4]. It is very important to keep track of all the energy resources that have been used and make their uses as economical as possible.

South Korea is the $8^{\text {th }}$ largest consumer of energy in the world and relies on the import of energy resources to fulfill its energy demand due to the lack of domestic energy resources. According to BP Statistical Review of World Energy 2018, the consumption of petroleum products in 1990 was 1 million barrels per day, the trend of using the petroleum products has been continuously increasing in South Korea and it reaches to 2.7 million barrels per day and oil demand rose to 0.3 million barrels per day in 2017.

About $44 \%$ of energy consumption in South Korea depends on the petroleum and other liquid, $29 \%$ on coal energy and $11 \%$ on nuclear energy in 2017. South Korea has to import about $98 \%$ of fossil fuel energy consumption. In 2017, it imported about 3 billion barrels/day of crude oil that made south Korea the $5^{\text {th }}$ biggest importer of crude. South Korea import most of the oil supply from the middle east. About $29 \%$ of crude oil comes from Saudia Arabia, 15\% from Kuwait and 12\% from Iran and Saudia Arabia [56]

The resources of natural gas in South Korea is almost negligible. It is even less than $1 \%$. There are not any international gas pipelines connected to the south Korea so the only source of importing gas is through tankers of Liquified natural gas. Still, South Korea is the $3^{\text {rd }}$ largest consumption of natural gas in the world.

The Korea Gas Corporation (KOGAS) is the largest company or organization in South Korea that imports the largest share of gas. The other local companies are allowed to import LNG only according to the terms and conditions of KOGAS [7].

According to US energy information administration, natural gas consumption was recorded in the year 2000 as 600 billion cubic feet. In 2005, it increases to 1200 billion cubic feet. The highest consumption was recorded in 2016, i.e. 1800 billion cubic feet and in 2017, it decrease to1400 cubic feet. The $17 \%$ share of all the natural gas consumption was used by the industrial sector, $30 \%$ was used by the residential consumers and only $3 \%$ was used by the transportation sector

\section{Literature Review}

South Korea heavily depends on fossil fuels and nuclear sources for the generation of electricity. About 2/3 of electricity generation of South Korea depends on fossil fuels and 1/3 depend on Nuclear resources. The Government made the initiative to increase its dependence on renewable energy sources which are more environmentally friendly.

According to Korea energy economics 2017, South Korea has generated about 550,441 GWh of electricity in 2017. The electricity generation in 2012 was about $5 \%$ lower than in the last decade. In $2016,40 \%$ of entire electricity was generated from coal, $30 \%$ was from nuclear, $22 \%$ was from natural gas and $4 \%$ was from renewable sources. The industrial sector consumed about $54 \%$ of generated electricity, the commercial sector consumed about $26 \%$ and the transportation sector consumed about $13 \%$ of generated electricity [8].

Since South Korea relies on the import of energy sources to fulfill its energy demand, it is very important to track the energy been generated and transmitted.

This study focused on the development of the primary energy factor for heat and electricity in South Korea. The PEF consider the energy consumption for the conveyance and transmission of the carriers of 
energy, furthermore, it also considers the productivity of conversion or conversions from Primary Energy (PE) to Final Energy (FE). The vitality execution of a building depends on the features of the buildings as well as on the features of energy supply [9].

The performance of any building regarding energy efficiency is the net of all the delivered energies to meet its energy requirements. [EN/TR 15615 (CEN 2008)]. The assessment of the energy performance of buildings has a twofold reason.

- The energy requirement of new and old buildings.

- The PEF value of the buildings.

For both at national and regional level building sectors, the concept of PEF is very important regarding the energy policy of the buildings. They can coordinate the decision among various carriers of energy used to meet the building vitality needs, in light of the fact that the building vitality execution appraisal results depend specifically on their values. The PEF can also direct to the reduction of $\mathrm{CO}_{2}$ emission, increase the efficiency of energy at the user's end.

There are two kinds of energy.

Primary energy

Secondary energy

Both energies have different dimensions and represent a different form of energy. They are also known as source energy [10,11]. The energy performance of two buildings cannot be compared together if they represent the different genres of energy. For the Primary energy of electricity estimation, the energy losses in the generation, transportation, and distribution of electricity also taken into consideration unlike in the secondary form of energy [12]. It takes more than 1 unit of energy resources like fossil fuels, petroleum, and natural gas to generate 1 unit of electricity [13]. Likewise, the energy resources like renewables, biomass, waste, and others should be taken into account while calculating the Primary energy. All the secondary sources of energy should include evaluating primary energy consumption [14]. Primary energy evaluation also predicts with greater accuracy about the carbon emission factor which is highly important for environmental sustainability.

Overgaard [15] argue that primary and secondary energy should be kept separated. It will help to present a clear picture of energy consumption. The PEF considers the energy consumption for the conveyance and transmission of the carriers of energy, furthermore, it also considers the productivity of conversion or conversions from Primary Energy (PE) to Final Energy (FE). [16,17]. Marcogaz [18] suggested that if the PEF is calculated using all the renewable energy sources, it will be called the Total primary energy factor. Pout [19] suggested the inclusion of both renewable and nonrenewable energy sources for the calculation of primary energy factor. Many studies suggesting the system boundaries before evaluating primary energy consumption. The system boundaries must include energy and no energy inputs

Dijk [20] and CEN [21] calculate the primary energy factor by taking account of the energy extraction from resources, conversion, transmission and usage. Molenbroek [22] suggested to include all the energy losses while calculating the primary energy factor.

\section{Methods and Materials}

\subsection{Indicators of Primary energy factor}

\subsubsection{Significance of Primary energy factor}

According to EN/TR 15615 (CEN 2008), the energy that has not been exposed to any change or change process is known as Primary energy. For instance the petroleum products. The final energy comes from primary energy after being transformation and passing through the multiple processes. 
The reason of calculating PEF is to weigh the carriers of energy with respect to the source of energies. It is basically the numerical coefficients, defined as

$$
\mathrm{PEF}=\text { Unit of energy transmitted / } \mathrm{n} \text { units of PE consumed to deliver it. }
$$

The PEF consider the energy consumption for the conveyance and transmission of the carriers of energy, furthermore it also considers the productivity of conversion or conversions from PE to FE. The vitality execution of a building depends on the features of the buildings as well as on the features of the energy supply.

The performance of any building regarding energy efficiency is the net of all the delivered energies to meet its energy requirements. [EN/TR 15615 (CEN 2008)]. The assessment of the energy performance of buildings has a twofold reason.

i. The energy requirement of new and old buildings.

ii. The PEF value of the buildings.

For both at national and regional level building sectors, the concept of PEF is very important regarding the energy policy of the buildings. They can coordinate the decision among various carriers of energy used to meet the building vitality needs, in light of the fact that the building vitality execution appraisal results depend specifically on their values. The PEF can also direct to the reduction of $\mathrm{CO}_{2}$ emission, increase the efficiency of energy at the user's end. There are three kinds of Primary energy factors. The fig. 1 below shows how the different PEF connected to each other.
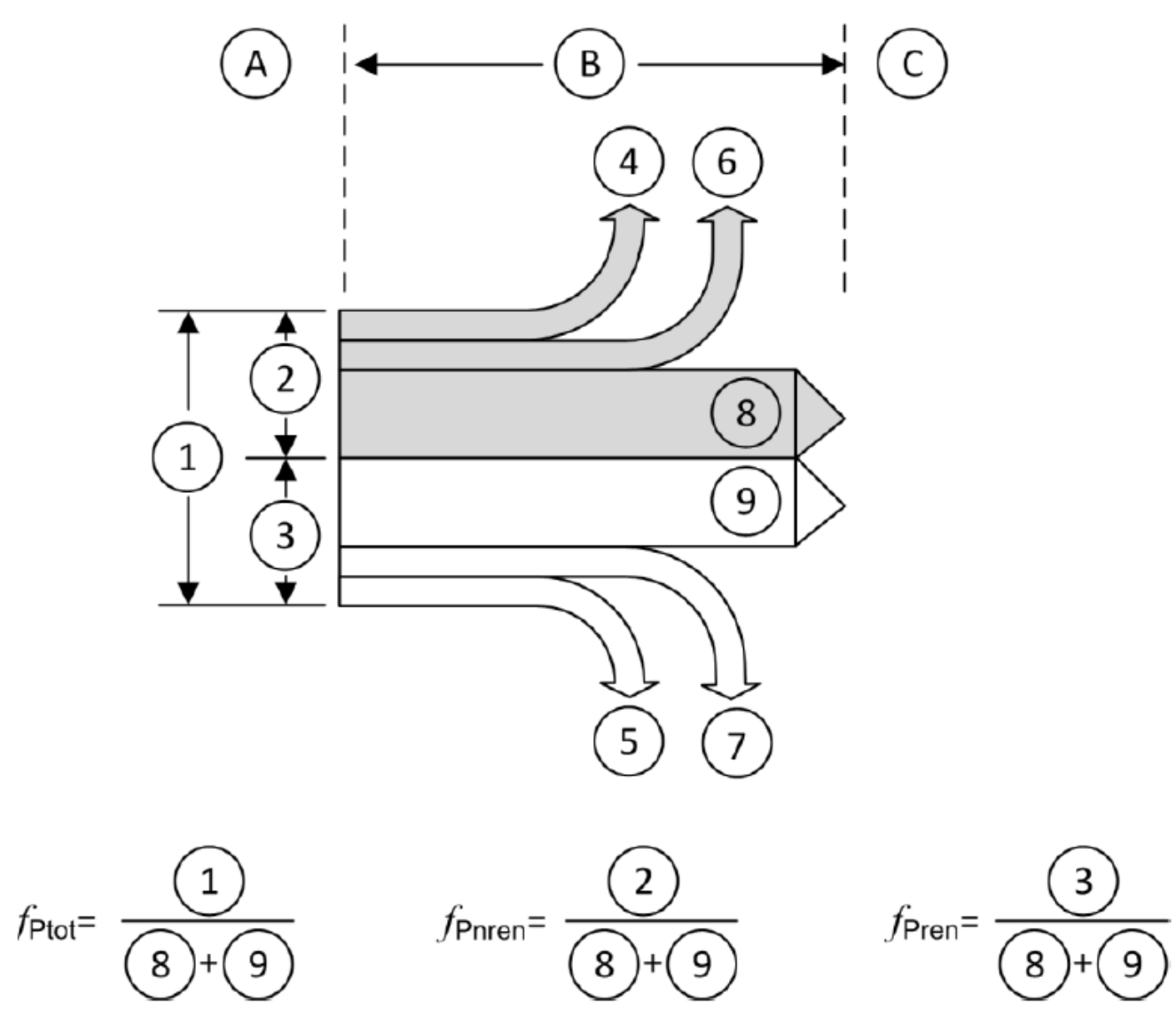

Figure 1. Primary energy factor and Primary energy flows 
$1=$ Total primary energy. Sum of both non-renewable and renewable primary energy.

$2=$ Portion of Non-Renewable Primary energy

$3=$ Portion of Renewable Primary energy

4= Energy related to infrastructure (Non-Renewable energy)

$5=$ Energy related to infrastructure (Renewable energy)

$6=$ Energy loss during conversion and transformation (Non-Renewable energy)

$7=$ Energy loss during conversion and transformation (Renewable energy)

$8=$ Final Non-renewable energy consumption

9= Final Renewable energy Consumption.

$\mathrm{f}_{\mathrm{p}}=$ Total Primary energy factor

$\mathrm{f}_{\text {nrew }}=$ Non-Renewable primary energy factor

$\mathrm{f}_{\text {ren }}=$ Renewable Primary energy factor

\subsubsection{Total Primary energy factor}

The total energy factor is the ratio of the sum of both renewable and non-renewable primary energy sources to the final energy delivered.

\subsubsection{Renewable Primary energy factor}

The renewable primary energy factor is the ratio of renewable primary energy sources to the final energy delivered.

\subsubsection{Non-renewable primary energy factor.}

The total energy factor is the ratio of the sum of both renewable and non-renewable primary energy to the final energy delivered.

\subsubsection{Establishing the boundaries of the system}

One of the most important stages is to define the boundary of the system. The Boundary of the system can be defined in ways.

\subsubsection{Entire Supply chain}

The entire supply chain method follows the Life cycle assessment (LCA) method and includes the expenditure of energy from the source extraction to the transportation, conversion into the useful energy, combustion, transportation and the final generation of electricity as shown in the figure below. 


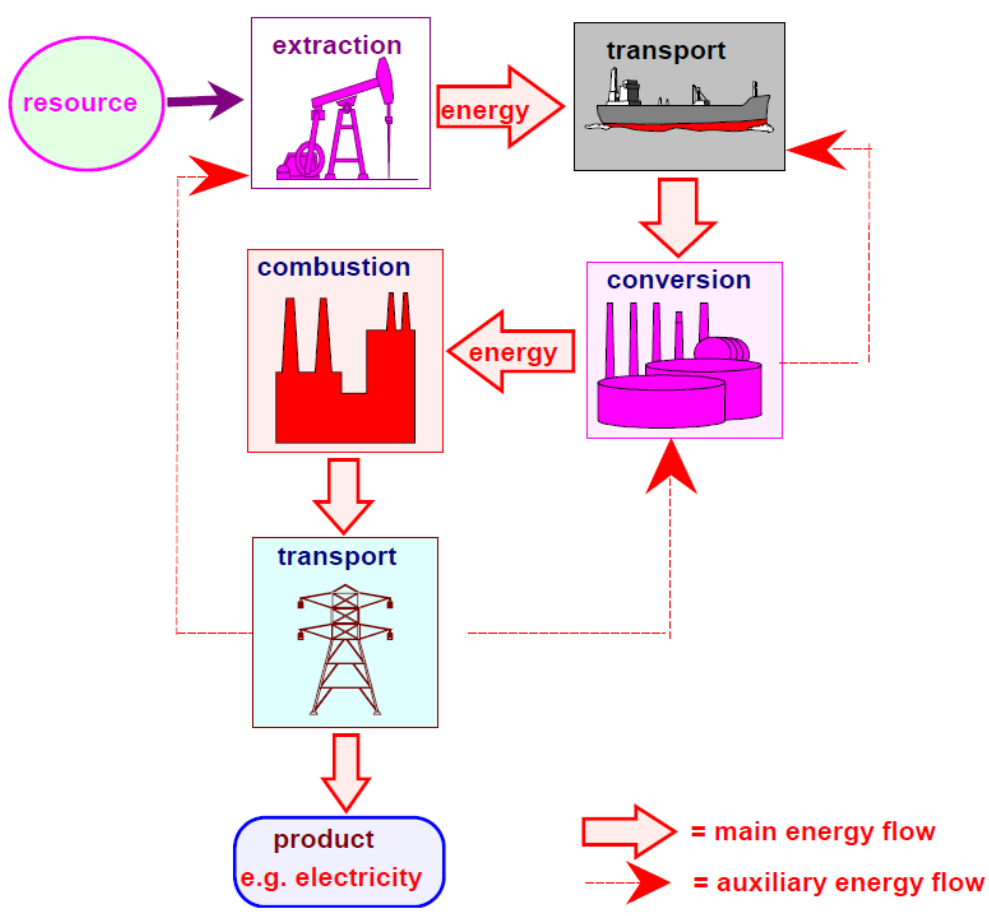

Figure 2. Schematic of entire supply chain energy flow

\subsubsection{Energy Conversion and transmission only}

The other method of defining the system boundary is to take the energy expenditure on the conversion and transmission only.

\subsubsection{Evaluation method for the Primary energy}

There are many methods for the evaluation of Primary energy according to the sources. The following study divided the evaluation of primary energy methods according to Non-Combustible non-renewable energy sources (Nuclear energy), Non-Combustible renewable energy sources (hydro, wind, steam, Solar, etc.) and fossil fuels.

The downstream Primary energy will also be taken into consideration apart from the primary energy of fuel if the entire supply chain has been defined as the boundary of the system.

\subsubsection{The accounting method for the nuclear electricity Generation}

\subsubsection{Direct equivalent method}

This energy evaluation method is particularly assigned for the Non- Combustible fuels by the UN. For the non-combustible fuels, the energy contents are hard to determine, the percentage of transformation efficiency of fuel into electricity in this method is $100 \%$. 


\subsubsection{Physical energy content method and Technical conversion efficiency method}

The technical conversion efficiency and physical energy content method have been extensively used by the International Energy Agency (IEA). These methods established the transformation efficiency of fuel into electricity only $33 \%$ and PEF value 1.00 .

\subsubsection{Accounting Method for the non-combustible Renewable energy sources.}

\subsubsection{Zero equivalent method (For Non-combustible fuels)}

This method does not take the primary energy into consideration for the transformation of fuels into electricity.

\subsubsection{Substitution method}

This method considers the potential energy of the source as the primary energy before any transformation occurs. For example, to use the substitution method the velocity and the mass of the air would be needed first to calculate the kinetic energy of the air if the energy source is a wind turbine. This method is extensively used by the Energy Information Administration US.

\subsubsection{Direct equivalent method}

The method assigned the PEF value of 1.00 to all the non-combustible renewable energy sources and not valid for combustible renewable energy sources like biomass. This method depicts the positive effects of non-combustible renewable energy sources on climate change.

\subsubsection{Physical energy content method}

The method considers the primary energy as initial or original energy before it has been used for different purposes. It assigned the primary energy factor value of unity for the transformation of noncombustible renewable energy sources into electricity. This method has been extensively used by IEA.

\subsubsection{Technical Conversion efficiencies}

In this method, the real data has been used to determine the conversion or transformation efficiency. It assigned the PEF value of unity for the transformation of all the non-combustible renewable energy sources into electricity.

\subsubsection{The accounting method for the combustible renewable energy sources}

The only 2 methods available to evaluate the Primary energy contents of Combustible renewable energy sources

- Zero equivalent method

- Technical Conversion efficiency method

The zero equivalent method is used if the purpose is to the evaluation of only non-renewable part of energy while the technical conversion efficiency method is used if the renewable part of the energy is taken into consideration. 


\subsubsection{The accounting method for the Combine heat and power (CHP)}

\subsubsection{International Energy Agency (IEA method)}

The method is largely used the Eurostat. The simplified version of this method is shown in the figure below

\section{IEA Method}
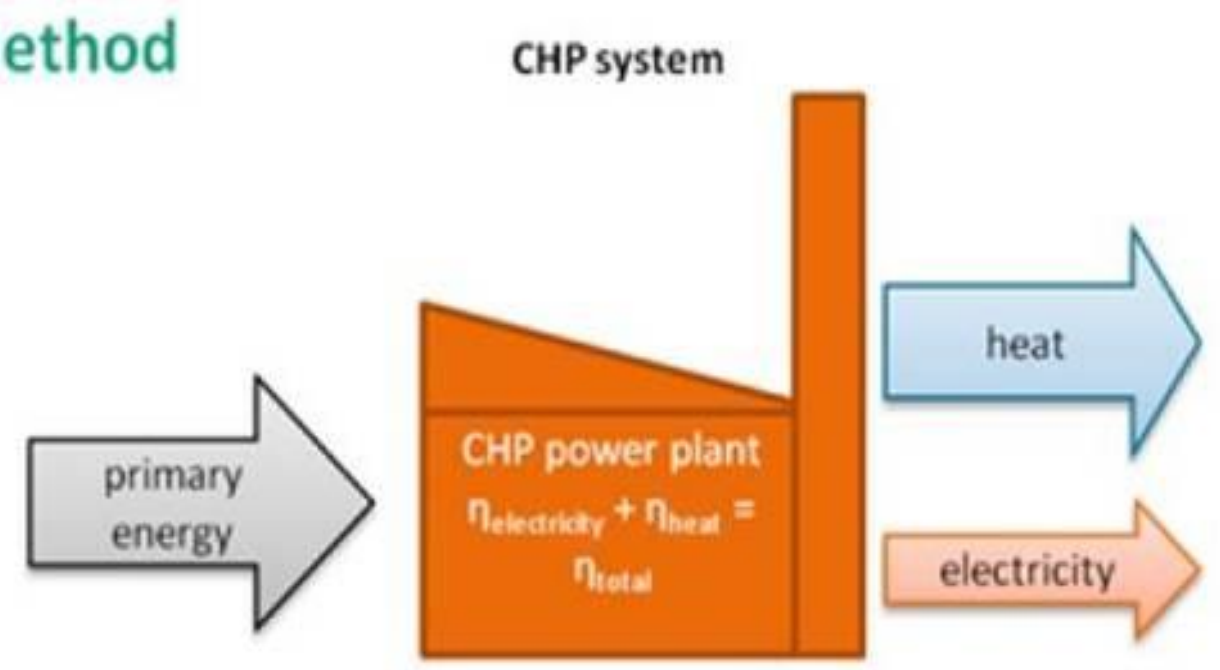

Figure 3. IEA method of evaluating CHP

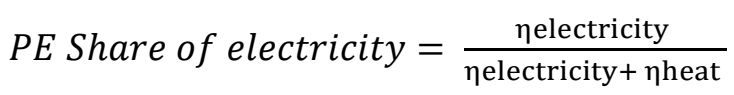

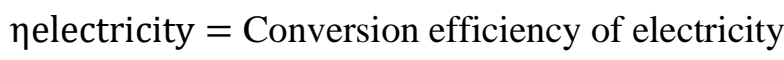

$$
\begin{aligned}
& \eta \text { heat }=\text { Conversion efficiency of heat }
\end{aligned}
$$

In this method, the amount of primary energy attributed to both heat and electricity according to their output share. The conversion efficiency of electricity is divided to the conversion efficiency of both heat and electricity. In CHP process, the conversion efficiency of heat is always higher than electricity so the greater share of Primary energy allocated to the heat.

\subsubsection{Finnish Method}

The Finnish way of accounting CHP is shown in the figure below. 

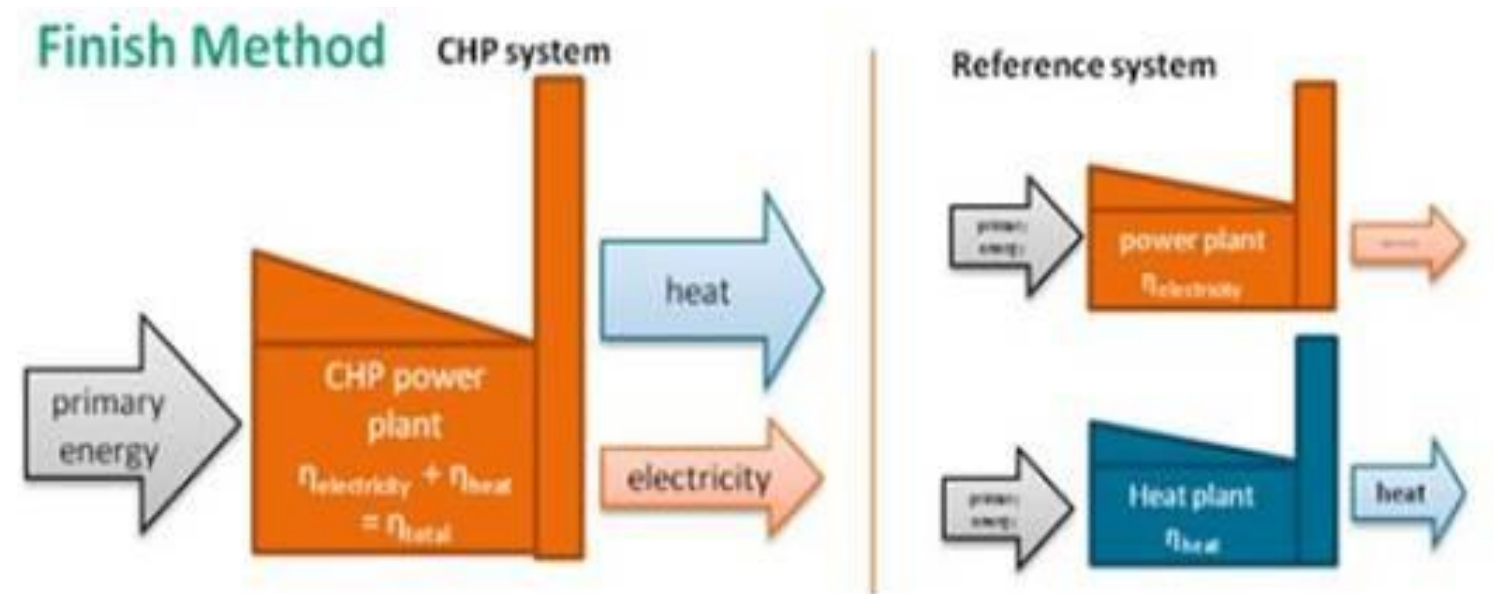

Figure 4. Finnish Method of evaluating CHP

$$
\begin{gathered}
\text { PE share of electricity }=(1-P E E) * \frac{\eta \mathrm{CHP}, \mathrm{el}}{\eta \mathrm{REF}, \mathrm{el}} \\
P E E=\frac{\text { PE Ref- PECHP }}{\text { PERef }}=1-\frac{1}{\frac{\eta \mathrm{CHP}, \text { heat }}{\eta \mathrm{REF}, \text { heat }}+\frac{\eta \mathrm{CHP}, \mathrm{el}}{\eta \mathrm{REF}, \mathrm{el}}} \\
P E E=\text { Primary energy savings compared to reference system } \\
\eta \mathrm{REF}, \mathrm{el}=\text { Conversion efficiency of the reference electricity system } \\
\eta \mathrm{REF} \text {, heat }=\text { Conversion efficiency of reference heat system }
\end{gathered}
$$

In the first step, the Primary energy saving of CHP calculated with reference to the separate system. The electrical and thermal efficiencies of the CHP process calculated with reference to the electrical and thermal efficiencies of the independent system

In the 2nd step, the primary energy assigned to both the electricity and heat can be calculated.

\subsubsection{List of equations used}

The equation used in this method are as follows

\subsubsection{Net electricity demand}

Gross electricity generated (1- Grid losses - Self Consumption)

\subsubsection{Primary energy demand}

Primary energy $(\mathrm{PE})$ demand $=\frac{\text { Gross electricity Generation } \times \text { PEF fuel }}{\text { efficiency }}$ 


\subsubsection{Raw Primary energy demand}

Raw primary energy demand $=\sum$ fuel $\frac{\text { Gross electricity generation } x \text { PEF fuel }}{\text { efficiency }}$

3.1.8.4.Heat calculation from the combined heat and power Plant

CHP Heat Generation $=\frac{\text { CHP electricity generation } \times(1-\text { self consumption })}{\text { electricity to heat ratio }}$

\subsubsection{Calculation of fuel Consumption by CHP}

Fuel Consumption $=\frac{\text { CHP electricity generation }+ \text { CHP heat generation }}{C H P \text { ef ficieny }}$

\subsubsection{Calculation of process efficiencies}

CHP efficiency of heat generation $=\frac{C H P \text { electricity generation }}{\text { CHP fuel consumption }}$

CHP efficiency of electricity generation $=\frac{C H P \text { heat generation }}{C H P \text { fuel consumption }}$

\subsubsection{Calculation of ratio efficiencies compared to alternative system efficiencies}

$$
\begin{aligned}
& \text { Ratio efficiency of electricity }=\frac{C H P \text { ef ficiency of electricty generated }}{40 \%} \\
& \text { Ratio efficiency Heat }=\frac{\text { CHP ef ficiency of heat generated }}{90 \%}
\end{aligned}
$$

\subsubsection{Calculations of the efficiency factor}

$$
\begin{aligned}
& \text { Sum of Ratios efficiency }=\text { Ratio efficiency electricity + Ratio efficiency Heat } \\
& \text { Efficiency Factor }(1-\text { PEE })=\text { Sum of Ratios efficiency - } 100 \%
\end{aligned}
$$

\subsubsection{Calculation of heat Bonus}

Heat Bonus $=$ Fuel Consumption $*$ Ratio efficiency heat $*(1-\mathrm{PEE}) * \mathrm{PEF}_{\text {fuel }}$

\subsubsection{Calculation of Primary energy factor}

Final PEF electricity $=\frac{\text { Raw Primary energy demand }- \text { Heat bonus } C H P}{\text { Net electricity demand }}$

\subsection{Development of Primary energy factor of electricity}

\subsubsection{Calculation Method 1 - Eurostat Methodology}

Method 1 is based on the Eurostat approach for the development of Primary energy factor. All the fuels consider for the development of the Primary energy factor of electricity has been given the value 1 and only the conversion and Transmission part of the energy has been considered. The figure below 
shows the road map for the development of the Primary energy factor. The efficiencies and PEF of different fuels calculated by Anke [23] have been used in this study.

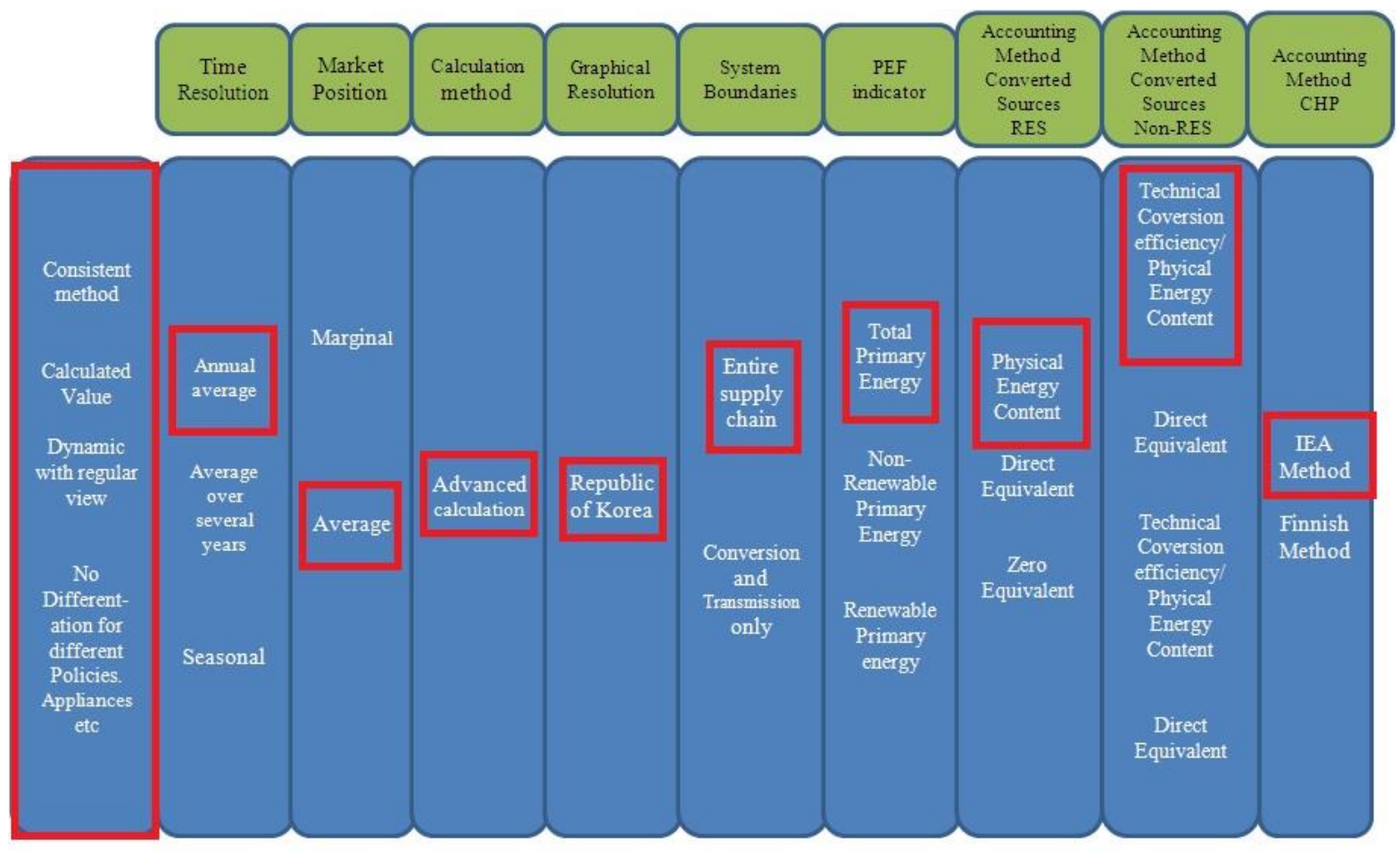

Figure 5. Decision path for the Eurostat Methodology

Table 1 shows the categories and indicators of the Eurostat Methodology.

Table 1. Categories and indicator for the Eurostat methodology

\begin{tabular}{|l|l|}
\hline Categories & Indicator \\
\hline Time Resolution & Annual Average \\
\hline Market Position & Average \\
\hline Method of calculation & Advanced \\
\hline Geographical region & Republic of Korea \\
\hline The boundary of the system & Only Transmission and Conversion Portion \\
\hline Indicator of PEF & Total PEF \\
\hline $\begin{array}{l}\text { The accounting method for renewable energy } \\
\text { sources }\end{array}$ & Physical energy content method \\
\hline $\begin{array}{l}\text { The accounting method for non-renewable energy } \\
\text { sources }\end{array}$ & Technical Conversion efficiency method \\
\hline
\end{tabular}


The accounting method for the Combined heat and power plant
International Energy agency method

Table 2. Assumed PEF values and efficiencies for Eurostat methodology

\begin{tabular}{|c|c|c|c|c|c|c|c|c|c|}
\hline Source & & 1980 & 1985 & 1990 & 1995 & 2000 & 2005 & \begin{tabular}{|l|}
2010 \\
\end{tabular} & 2015 \\
\hline \multirow[t]{2}{*}{ Hydro } & Efficiency & \multicolumn{8}{|c|}{$45 \%$} \\
\hline & PEF & & \multicolumn{7}{|c|}{1} \\
\hline \multirow[t]{2}{*}{ Nuclear } & Efficiency & & \multicolumn{7}{|c|}{$33 \%$} \\
\hline & PEF & & \multicolumn{7}{|c|}{1} \\
\hline \multirow[t]{2}{*}{ Coal } & Efficiency & $31 \%$ & $31 \%$ & $33 \%$ & $35 \%$ & $35 \%$ & $37 \%$ & $38 \%$ & $38 \%$ \\
\hline & $\mathrm{PEF}$ & \multicolumn{8}{|c|}{1} \\
\hline \multirow[t]{2}{*}{ Petroleum } & Efficiency & $31 \%$ & $35 \%$ & $38 \%$ & $40 \%$ & $41 \%$ & $43 \%$ & $45 \%$ & $47 \%$ \\
\hline & PEF & \multicolumn{8}{|c|}{1} \\
\hline \multirow[t]{2}{*}{ LNG } & Efficiency & $21 \%$ & $22 \%$ & $27 \%$ & $27 \%$ & $29 \%$ & $30 \%$ & $31 \%$ & $31 \%$ \\
\hline & $\mathrm{PEF}$ & \multicolumn{8}{|c|}{1} \\
\hline \multirow[t]{2}{*}{ Steam } & Efficiency & \multicolumn{8}{|c|}{$45 \%$} \\
\hline & PEF & \multicolumn{8}{|c|}{1} \\
\hline \multirow[t]{2}{*}{ Renewable } & Efficiency & \multicolumn{8}{|c|}{$45 \%$} \\
\hline & PEF & \multicolumn{8}{|c|}{1} \\
\hline
\end{tabular}

The fig. 6 shows the roadmap to the calculation of the PEF of electricity according to Eurostat Methodology

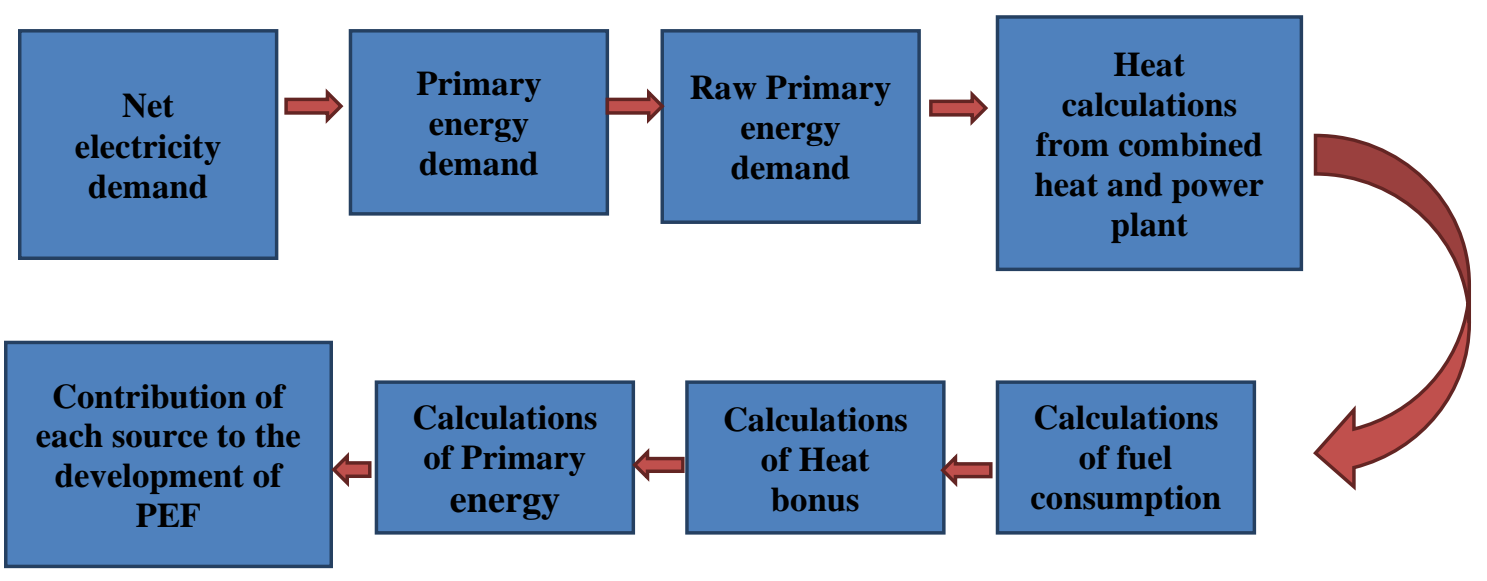




\subsection{2.}

\subsubsection{Figure 6. Roadmap to the calculation of primary energy factor (Eurostat Methodology)}

This method follows the Life Cycle Analysis (LCA) approach and only the non-renewable portion of the Primary energy factor has been considered. The entire supply chain has been taking into account for this method and the Finnish method has been used for accounting the CHP. For Fossil Fuel, the Primary energy factor for the coal, Petroleum, and LNG has been considered as 1.07, 1.11 and 1.13 for LCA Non-renewable PEF. The Fig. 7 shows the road map for the calculation method 2.

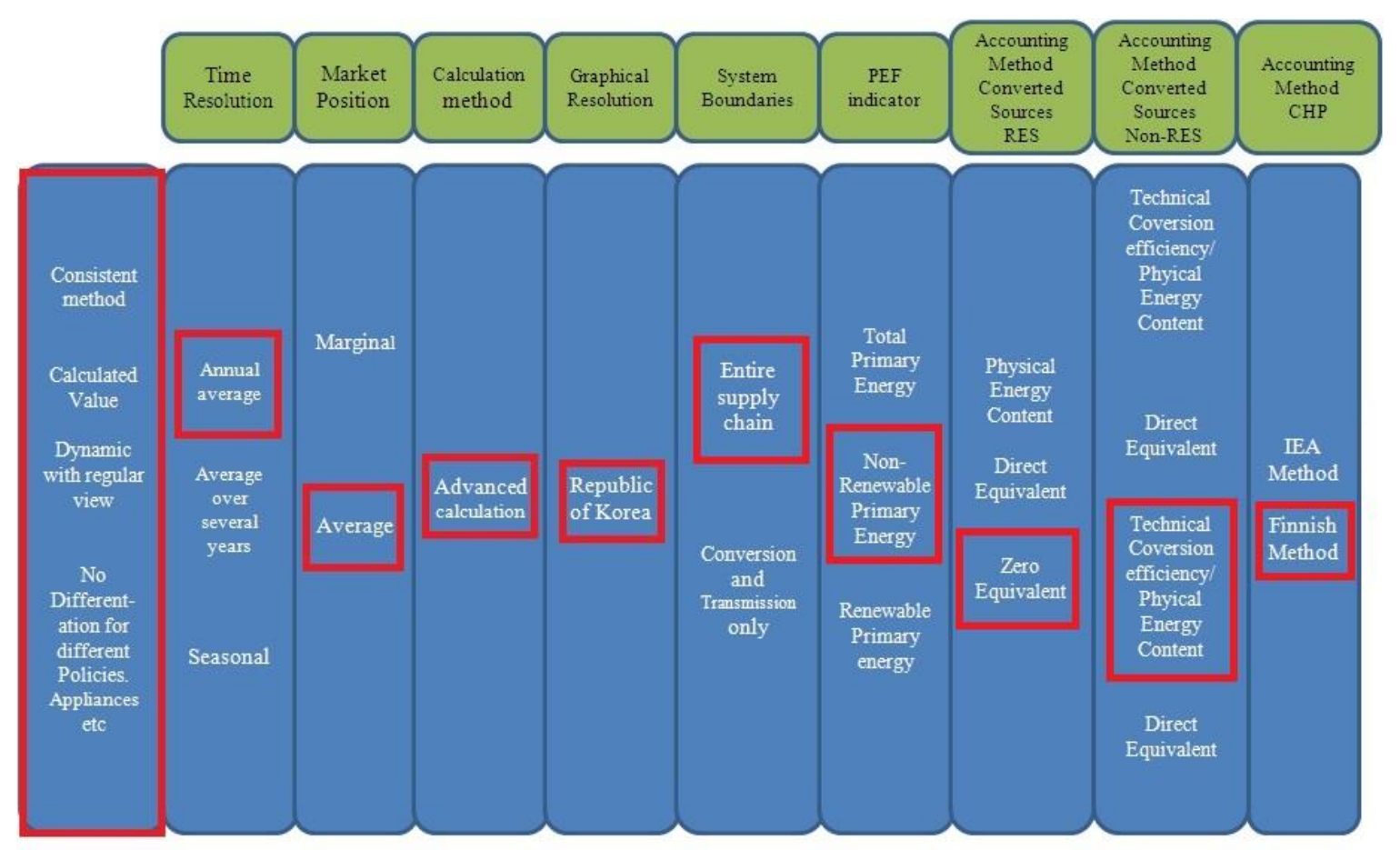

Figure 7. Decision path for the Life Cycle Approach

The table below shows the categories and indicator for the Life Cycle Approach

Table 3. Categories and indicator for the Life Cycle Approach

\begin{tabular}{|l|l|}
\hline Categories & Indicator \\
\hline Time Resolution & Annual Average \\
\hline Market Position & Average \\
\hline Method of calculation & Advanced \\
\hline
\end{tabular}




\begin{tabular}{|l|l|}
\hline Geographical region & Republic of Korea \\
\hline The boundary of the system & Entire supply chain \\
\hline Indicator of PEF & Non-Renewable Primary energy \\
\hline $\begin{array}{l}\text { The accounting method for renewable energy } \\
\text { sources }\end{array}$ & Zero equivalent \\
\hline $\begin{array}{l}\text { The accounting method for non-renewable energy } \\
\text { sources }\end{array}$ & $\begin{array}{l}\text { Technical Conversion efficiency/ Physical energy } \\
\text { content method }\end{array}$ \\
\hline $\begin{array}{l}\text { The accounting method for the Combined heat } \\
\text { and power plant }\end{array}$ & Finnish Method \\
\hline
\end{tabular}

The table below shows the efficiency and PEF fuel for the Life Cycle Approach.

Table 4. Assumed PEF values and efficiencies for the Life Cycle Approach

\begin{tabular}{|c|c|c|c|c|c|c|c|c|c|}
\hline Source & & 1980 & 1985 & 1990 & 1995 & 2000 & 2005 & 2010 & 2015 \\
\hline \multirow[t]{2}{*}{ Hydro } & Efficiency & \multicolumn{8}{|c|}{$45 \%$} \\
\hline & PEF & \multicolumn{8}{|c|}{0.06} \\
\hline \multirow[t]{2}{*}{ Nuclear } & Efficiency & \multicolumn{8}{|c|}{$33 \%$} \\
\hline & PEF & \multicolumn{8}{|c|}{1} \\
\hline \multirow[t]{2}{*}{ Coal } & Efficiency & $31 \%$ & $31 \%$ & $33 \%$ & $35 \%$ & $35 \%$ & $37 \%$ & $38 \%$ & $38 \%$ \\
\hline & PEF & \multicolumn{8}{|c|}{1.07} \\
\hline \multirow[t]{2}{*}{ Petroleum } & Efficiency & $31 \%$ & $35 \%$ & $38 \%$ & $40 \%$ & $41 \%$ & $43 \%$ & $45 \%$ & $47 \%$ \\
\hline & PEF & \multicolumn{8}{|c|}{1.11} \\
\hline \multirow[t]{2}{*}{ LNG } & Efficiency & $21 \%$ & $22 \%$ & $27 \%$ & $27 \%$ & $29 \%$ & $30 \%$ & $31 \%$ & $31 \%$ \\
\hline & PEF & \multicolumn{8}{|c|}{1.13} \\
\hline \multirow[t]{2}{*}{ Steam } & Efficiency & \multicolumn{8}{|c|}{$45 \%$} \\
\hline & PEF & \multicolumn{8}{|c|}{0.07} \\
\hline \multirow[t]{2}{*}{ Renewable } & Efficiency & \multicolumn{8}{|c|}{$45 \%$} \\
\hline & PEF & \multicolumn{8}{|c|}{0.08} \\
\hline
\end{tabular}

Fig 8 shows the roadmap to the development of PEF of electricity according to Life Cycle methodology. 

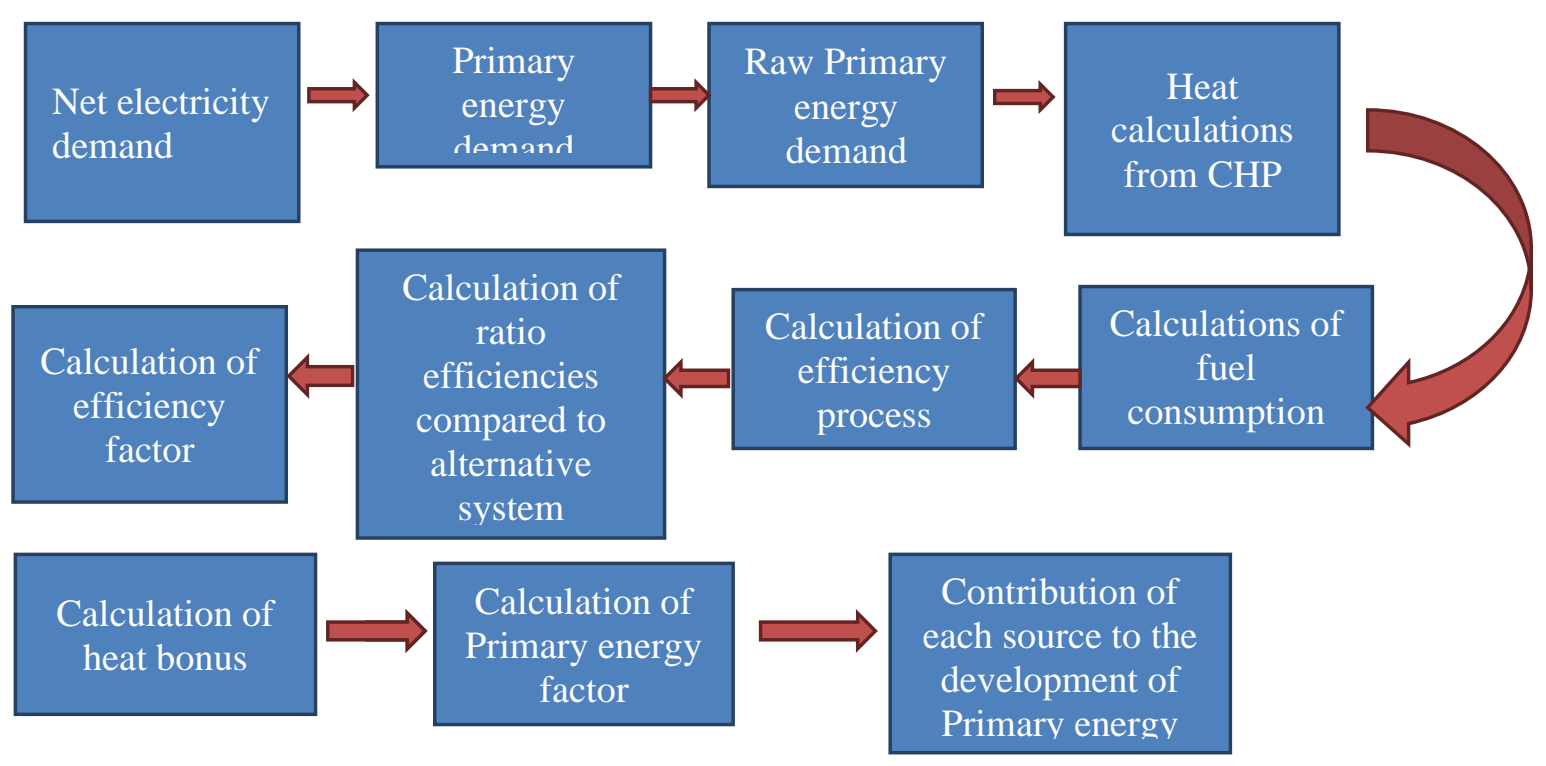

Figure 8. Roadmap to the development of primary energy factor (Life Cycle Methodology)

\subsubsection{Calculation Method 3 - Modified Eurostat Methodology}

The calculation method 3 is the modification of calculation method 1 and follows the same Eurostat methodology of accounting energy. The basic difference between them is the accounting method for the Combined Heat and Power Plant. For Method 1, the IEA method has been used and for Method 3, the finish method has been used to account for the CHP. 


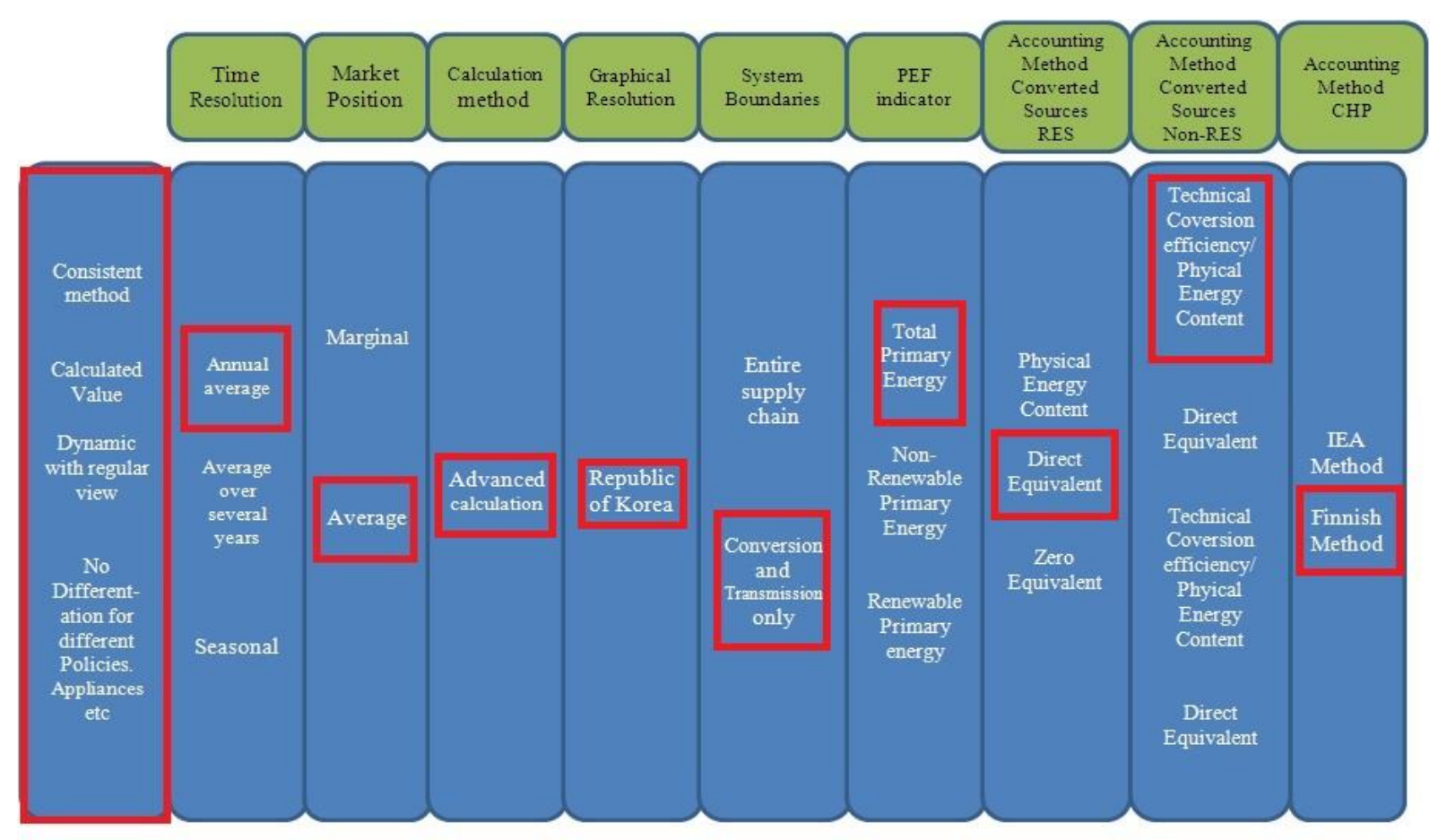

Figure 9. Decision path for the Modified Eurostat Methodology

The table below shows the categories and indicator for the Modified Eurostat Methodology

Table 5. Categories and indicator for the Modified Eurostat methodology

\begin{tabular}{|l|l|}
\hline Categories & Indicator \\
\hline Time Resolution & Annual Average \\
\hline Market Position & Average \\
\hline Method of calculation & Advanced \\
\hline Geographical region & Republic of Korea \\
\hline The boundary of the system & Only Conversion and transmission Portion \\
\hline Indicator of PEF & Total Primary energy \\
\hline $\begin{array}{l}\text { The accounting method for renewable energy } \\
\text { sources }\end{array}$ & Direct equivalent \\
\hline $\begin{array}{l}\text { The accounting method for non-renewable energy } \\
\text { sources }\end{array}$ & $\begin{array}{l}\text { Technical Conversion efficiency/ Physical energy } \\
\text { content method }\end{array}$ \\
\hline $\begin{array}{l}\text { The accounting method for the Combined heat } \\
\text { and power plant }\end{array}$ & Finnish Method \\
\hline
\end{tabular}


The table 6 below shows the efficiency and PEF fuel for the calculation method

Table 6. Assumed PEF values and efficiencies for the Modified Eurostat methodology

\begin{tabular}{|c|c|c|c|c|c|c|c|c|c|}
\hline Source & & 1980 & 1985 & 1990 & 1995 & 2000 & 2005 & 2010 & 2015 \\
\hline \multirow[t]{2}{*}{ Hydro } & Efficiency & \multicolumn{8}{|c|}{$45 \%$} \\
\hline & PEF & \multicolumn{8}{|c|}{ 政 } \\
\hline \multirow[t]{2}{*}{ Nuclear } & Efficiency & \multicolumn{8}{|c|}{$33 \%$} \\
\hline & PEF & \multicolumn{8}{|c|}{1} \\
\hline \multirow[t]{2}{*}{ Coal } & Efficiency & $31 \%$ & $31 \%$ & $33 \%$ & $35 \%$ & $35 \%$ & $37 \%$ & $38 \%$ & $38 \%$ \\
\hline & PEF & \multicolumn{8}{|c|}{1} \\
\hline \multirow[t]{2}{*}{ Petroleum } & Efficiency & $31 \%$ & $35 \%$ & $38 \%$ & $40 \%$ & $41 \%$ & $43 \%$ & $45 \%$ & $47 \%$ \\
\hline & $\mathrm{PEF}$ & \multicolumn{8}{|c|}{1} \\
\hline \multirow[t]{2}{*}{ LNG } & Efficiency & $21 \%$ & $22 \%$ & $27 \%$ & $27 \%$ & $29 \%$ & $30 \%$ & $31 \%$ & $31 \%$ \\
\hline & PEF & \multicolumn{8}{|c|}{1} \\
\hline \multirow[t]{2}{*}{ Steam } & Efficiency & \multicolumn{8}{|c|}{$45 \%$} \\
\hline & PEF & \multicolumn{8}{|c|}{1} \\
\hline \multirow[t]{2}{*}{ Renewable } & Efficiency & \multicolumn{8}{|c|}{$45 \%$} \\
\hline & PEF & \multicolumn{8}{|c|}{1} \\
\hline
\end{tabular}

The main difference between the modified and Eurostat modified methodology is the evaluation of electricity generation from CHP. The modified Eurostat methodology uses the Finnish method for the analysis of electricity generated from CHP unlike Eurostat methodology which uses the IEA method.

\subsubsection{Calculation Method 4 - Upper-end Method}

This method has been developed to explain the upper end of the Primary energy factor development option. This method taking into account the entire supply chain and follows the LCA approach for non-renewable fuels. The Primary energy factor of 1.11 has been chosen as an approximation of LCA total primary energy. The figure below shows the roadmap for the development of the Primary energy factor of electricity. 


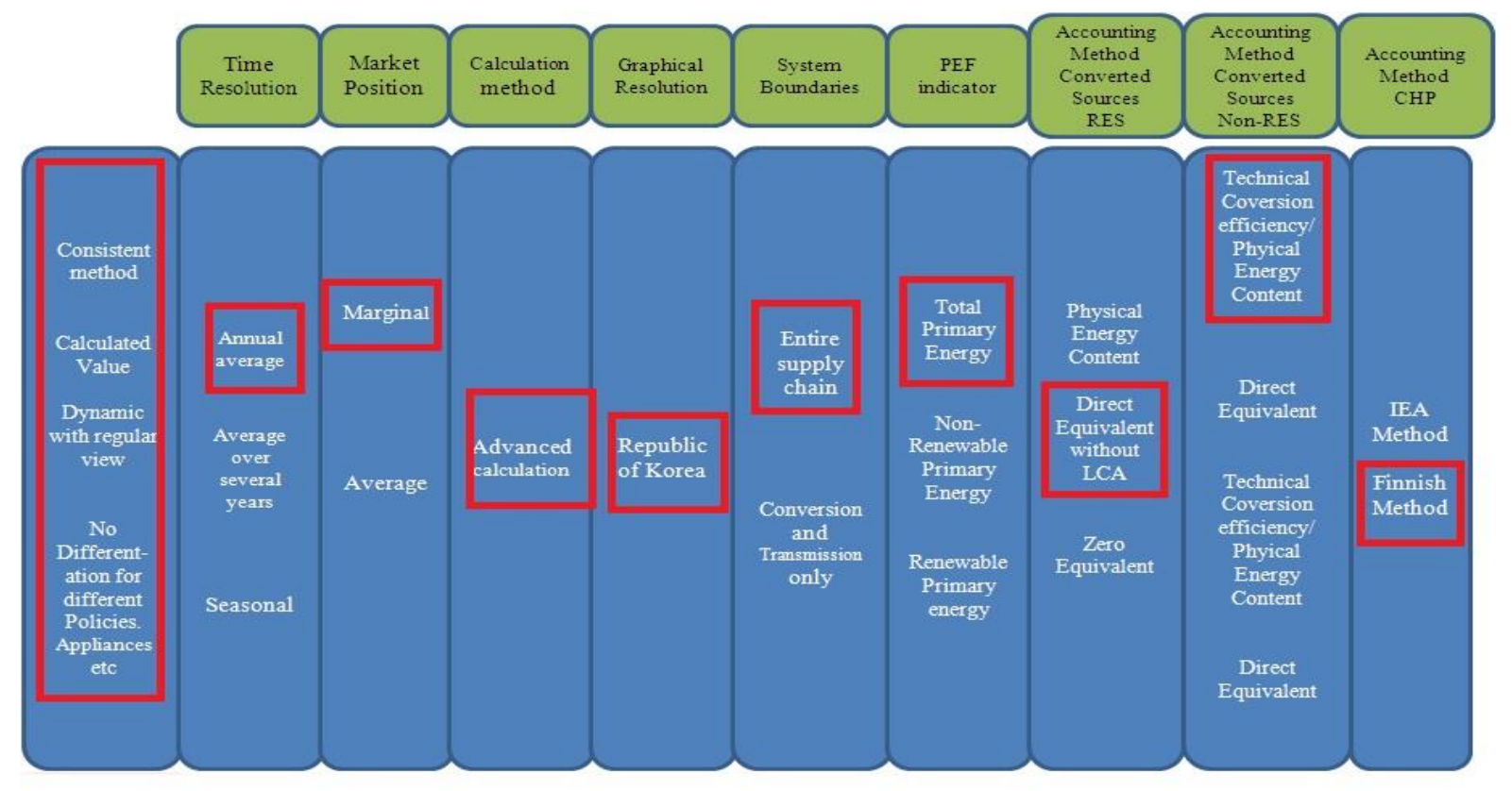

Figure 10. Decision path for the Upper-end Methodology

The table below shows the categories and indicator for the calculation method 4

Table 7. Categories and indicator for the Upper-end methodology

\begin{tabular}{|l|l|}
\hline Categories & Indicator \\
\hline Time Resolution & Annual Average \\
\hline Market Position & Average \\
\hline Method of calculation & Advanced \\
\hline Geographical region & Republic of Korea \\
\hline The boundary of the system & Entire Supply chain \\
\hline Indicator of PEF & Total Primary energy \\
\hline $\begin{array}{l}\text { The accounting method for renewable energy } \\
\text { sources }\end{array}$ & Direct equivalent with LCA \\
\hline $\begin{array}{l}\text { The accounting method for non-renewable energy } \\
\text { sources }\end{array}$ & $\begin{array}{l}\text { Technical Conversion efficiency/ Physical energy } \\
\text { content method }\end{array}$ \\
\hline $\begin{array}{l}\text { The accounting method for the Combined heat } \\
\text { and power plant }\end{array}$ & Finnish Method \\
\hline
\end{tabular}

The table below shows the efficiency and PEF fuel for the Upper-end Methodology. 
Table 8. Assumed PEF values and efficiencies for the Modified Eurostat methodology

\begin{tabular}{|c|c|c|c|c|c|c|c|c|c|}
\hline Source & & 1980 & 1985 & 1990 & 1995 & 2000 & 2005 & 2010 & 2015 \\
\hline \multirow[t]{2}{*}{ Hydro } & Efficiency & \multicolumn{8}{|c|}{$45 \%$} \\
\hline & PEF & \multicolumn{8}{|c|}{1} \\
\hline \multirow[t]{2}{*}{ Nuclear } & Efficiency & \multicolumn{8}{|c|}{$33 \%$} \\
\hline & PEF & \multicolumn{8}{|c|}{1} \\
\hline \multirow[t]{2}{*}{ Coal } & Efficiency & $31 \%$ & $31 \%$ & $33 \%$ & $35 \%$ & $35 \%$ & $37 \%$ & $38 \%$ & $38 \%$ \\
\hline & PEF & \multicolumn{8}{|c|}{1.11} \\
\hline \multirow[t]{2}{*}{ Petroleum } & Efficiency & $31 \%$ & $35 \%$ & $38 \%$ & $40 \%$ & $41 \%$ & $43 \%$ & $45 \%$ & $47 \%$ \\
\hline & PEF & \multicolumn{8}{|c|}{1.11} \\
\hline \multirow[t]{2}{*}{ LNG } & Efficiency & $21 \%$ & $22 \%$ & $27 \%$ & $27 \%$ & $29 \%$ & $30 \%$ & $31 \%$ & $31 \%$ \\
\hline & PEF & \multicolumn{8}{|c|}{1.11} \\
\hline \multirow[t]{2}{*}{ Steam } & Efficiency & \multicolumn{8}{|c|}{$45 \%$} \\
\hline & PEF & \multicolumn{8}{|c|}{1} \\
\hline \multirow[t]{2}{*}{ Renewable } & Efficiency & \multicolumn{8}{|c|}{$45 \%$} \\
\hline & PEF & \multicolumn{8}{|c|}{1} \\
\hline
\end{tabular}

\section{Results and Discussions}

4.1. Development of Primary energy factor of electricity

\subsubsection{Calculation Method 1- Eurostat Methodology}

\subsubsection{Calculations of net electricity demand}

The Net electricity demand in South Korea has been shown in table 13 by considering the electricity generation from different sources. All values are in $\mathrm{GWh}$

Table 9. Gross electricity generation in South Korea (GWh)

\begin{tabular}{|l|l|l|l|l|l|l|l|l|}
\hline \multicolumn{7}{|c|}{ All values are in GWh } \\
\hline Source & $\mathbf{1 9 8 0}$ & $\mathbf{1 9 8 5}$ & $\mathbf{1 9 9 0}$ & $\mathbf{1 9 9 5}$ & $\mathbf{2 0 0 0}$ & $\mathbf{2 0 0 5}$ & $\mathbf{2 0 1 0}$ & $\mathbf{2 0 1 5}$ \\
\hline Hydro & 2,709 & 3,659 & 6,361 & 5,478 & 5,610 & 5,189 & 6,472 & 5,796 \\
\hline Nuclear & 2,897 & 16,745 & 52,887 & 67,029 & 108,964 & 146,779 & 148,956 & 164,762 \\
\hline
\end{tabular}




\begin{tabular}{|l|l|l|l|l|l|l|l|l|}
\hline Coal & 2,530 & 17,639 & 19,961 & 48,813 & 97,538 & 133,658 & 197,916 & 204,230 \\
\hline Petroleum & 32,071 & 19,964 & 18,856 & 42,045 & 26,142 & 17,733 & 12,878 & 31,616 \\
\hline LNG & - & 250 & 9,604 & 21,296 & 28,156 & 58,118 & 96,734 & 100,783 \\
\hline Steam & 34,305 & 37,411 & 47,098 & 89,252 & 119,947 & 151,207 & 211,449 & 216,378 \\
\hline Renewable & 29 & 23.61 & 9.26 & 12.22 & 24.76 & 46.04 & 70.5 & 149 \\
\hline $\begin{array}{l}\text { Combined } \\
\text { cycle }\end{array}$ & 258 & 58 & 619 & 20,521 & 26,863 & 57,457 & 94,012 & 100,598 \\
\hline \begin{tabular}{l} 
others \\
\hline Gross
\end{tabular} & - & - & - & - & 3903 & 3163 & 12064 & 20904 \\
\hline $\begin{array}{l}\text { electricity } \\
\text { generation }\end{array}$ & 77.262 & 97,757 & 156,183 & 295,485 & 419,253 & 577,265 & 786,545 & 857,908 \\
\hline $\begin{array}{l}\text { Self } \\
\text { Consumption }\end{array}$ & $5.1 \%$ & $5.1 \%$ & $5.0 \%$ & $4.9 \%$ & $4.8 \%$ & $4.7 \%$ & $4.6 \%$ & $4.5 \%$ \\
\hline Grid losses & $7.2 \%$ & $7.2 \%$ & $7.0 \%$ & $6.9 \%$ & $6.8 \%$ & $6.7 \%$ & $5.9 \%$ & $5.9 \%$ \\
\hline $\begin{array}{l}\text { Net electricity } \\
\text { demand }\end{array}$ & 65,075 & 85,048 & 137,441 & 260,026 & 373,135 & 513,765 & 707,890 & 772,117 \\
\hline & & & & & & & & \\
\hline
\end{tabular}

\subsubsection{Calculations of Raw Primary energy demand (RPED)}

The RPED of the electricity generation for the Eurostat methodology has been shown in table 14 .

Table 10. Raw Primary energy demand for electricity generation in South Korea

\begin{tabular}{|c|c|c|c|c|c|c|c|c|c|}
\hline \multicolumn{10}{|c|}{ All values are in GWh } \\
\hline Source & Factors & 1980 & 1985 & 1990 & 1995 & 2000 & 2005 & 2010 & 2015 \\
\hline \multirow[t]{4}{*}{ Hydro } & $\begin{array}{l}\text { Total } \\
\text { electricity } \\
\text { generation }\end{array}$ & 2,709 & 3,659 & 6,361 & 5,478 & 5,610 & 5,189 & 6,472 & 5,796 \\
\hline & $\begin{array}{l}\text { PE } \\
\text { demand }\end{array}$ & 2,709 & 3,659 & 6,361 & 5,478 & 5,610 & 5,189 & 6,472 & 5,796 \\
\hline & Efficiency & \multicolumn{8}{|c|}{$45 \%$} \\
\hline & $\mathrm{PEF}_{\text {fuel }}$ & \multicolumn{8}{|c|}{1} \\
\hline
\end{tabular}




\begin{tabular}{|c|c|c|c|c|c|c|c|c|c|}
\hline \multirow[t]{4}{*}{ Nuclear } & $\begin{array}{l}\text { Total } \\
\text { electricity } \\
\text { generation }\end{array}$ & 2,897 & 16,745 & 52,887 & 67,029 & 108,964 & 146,779 & 148,596 & 164,762 \\
\hline & $\begin{array}{l}\text { PE } \\
\text { demand }\end{array}$ & 8,778 & 50,742 & 160,263 & 203,118 & 330,193 & 444,784 & 450,290 & 499,278 \\
\hline & Efficiency & \multicolumn{8}{|c|}{$33 \%$} \\
\hline & PEF fuel & \multicolumn{8}{|c|}{1} \\
\hline \multirow[t]{4}{*}{ Coal } & $\begin{array}{l}\text { Total } \\
\text { electricity } \\
\text { generation }\end{array}$ & 2,530 & 17,639 & 19,961 & 48,813 & 97,538 & 133,658 & 197,916 & 213,803 \\
\hline & $\begin{array}{l}\text { PE } \\
\text { demand }\end{array}$ & 8,161 & 56,900 & 60,487 & 139,465 & 278,680 & 361,237 & 520,831 & 562,639 \\
\hline & Efficiency & $31 \%$ & $31 \%$ & $33 \%$ & $35 \%$ & $35 \%$ & $37 \%$ & $38 \%$ & $38 \%$ \\
\hline & $\mathrm{PEF}$ fuel & \multicolumn{8}{|c|}{1} \\
\hline \multirow[t]{4}{*}{ Petroleum } & $\begin{array}{l}\text { Total } \\
\text { electricity } \\
\text { generation }\end{array}$ & 32,071 & 19,964 & 18,856 & 42,045 & 26,142 & 17,733 & 12,878 & 31,616 \\
\hline & $\begin{array}{l}\text { PE } \\
\text { demand }\end{array}$ & 103,454 & 57,040 & 49,621 & 105,112 & 63,760 & 41,239 & 29,948 & 70,257 \\
\hline & Efficiency & $31 \%$ & $35 \%$ & $38 \%$ & $40 \%$ & $41 \%$ & $43 \%$ & $43 \%$ & $45 \%$ \\
\hline & $\mathrm{PEF}$ fuel & \multicolumn{8}{|c|}{1} \\
\hline \multirow[t]{4}{*}{ LNG } & $\begin{array}{l}\text { Total } \\
\text { electricity } \\
\text { generation }\end{array}$ & & 250 & 9,604 & 21,296 & 28,146 & 58,118 & 96,734 & 100,783 \\
\hline & $\begin{array}{l}\text { PE } \\
\text { demand }\end{array}$ & & 1,136 & 35,570 & 78,874 & 97,055 & 193,726 & 312,045 & 325,106 \\
\hline & Efficiency & $21 \%$ & $22 \%$ & $27 \%$ & $27 \%$ & $29 \%$ & $30 \%$ & $31 \%$ & $31 \%$ \\
\hline & PEF fuel & \multicolumn{8}{|c|}{1} \\
\hline \multirow[t]{4}{*}{ Steam } & $\begin{array}{l}\text { Total } \\
\text { electricity } \\
\text { generation }\end{array}$ & 34,305 & 37,411 & 47,098 & 89,252 & 119,947 & 151,207 & 211,449 & 216,378 \\
\hline & $\begin{array}{l}\text { PE } \\
\text { demand }\end{array}$ & 34,305 & 37,411 & 47,098 & 89,252 & 119,947 & 151,207 & 211,449 & 216,378 \\
\hline & Efficiency & \multicolumn{8}{|c|}{$45 \%$} \\
\hline & PEF fuel & & & & & 1 & & & \\
\hline
\end{tabular}




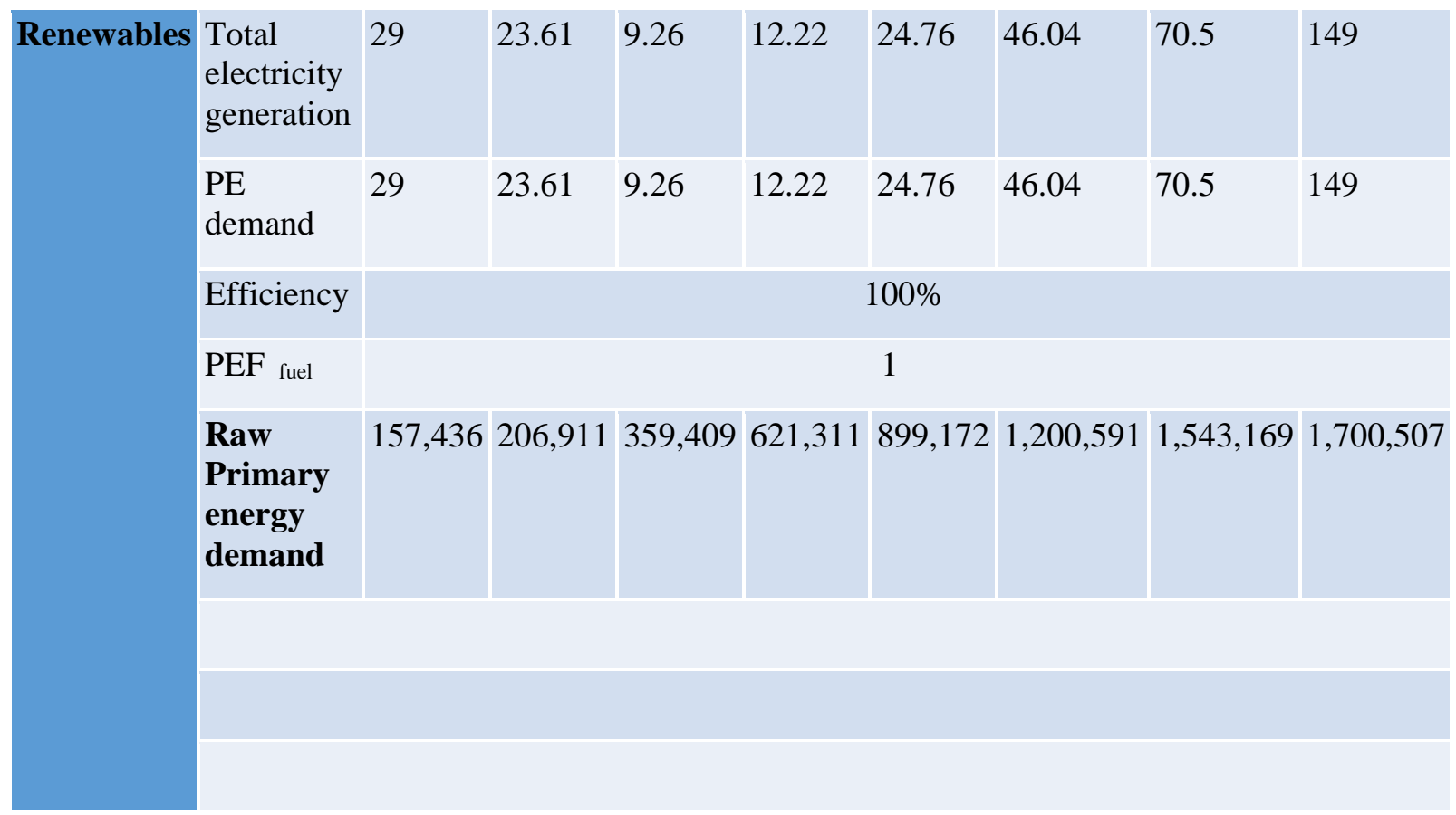

\subsubsection{Generation of heat calculations from Combined heat and power plant (CHP)}

The heat generated from the CHP has been calculated in table 15. The self- consumption is assumed to be $8 \%$,

Table 11. Calculation of CHP heat generation (GWh)

\begin{tabular}{|c|c|c|c|c|c|c|c|c|c|}
\hline Name & & 1980 & 1985 & 1990 & 1995 & 2000 & 2005 & 2010 & 2015 \\
\hline \multirow{4}{*}{ CHP } & $\begin{array}{l}\text { Electricity } \\
\text { generation }\end{array}$ & 258 & 58 & 619 & 20,521 & 26,863 & 57,457 & 94,012 & 100,598 \\
\hline & Electricity/heat & $36 \%$ & $38 \%$ & $38 \%$ & $39 \%$ & $40 \%$ & $42 \%$ & $42 \%$ & $46 \%$ \\
\hline & 1-(Self-Cons) & $92 \%$ & $92 \%$ & $92 \%$ & $92 \%$ & $92 \%$ & $92 \%$ & $92 \%$ & $92 \%$ \\
\hline & $\begin{array}{l}\text { Heat } \\
\text { generation }\end{array}$ & 659 & 166 & 1,498 & 48,408 & 61,784 & 125,858 & 205,931 & 201,196 \\
\hline
\end{tabular}

\subsubsection{Calculations of fuel consumption by CHP}

The calculation of fuel consumption for the CHP electricity and heat generation has been shown in table 16. 
Table 12. Calculations of CHP Fuel consumption (GWh)

\begin{tabular}{|c|c|c|c|c|c|c|c|c|c|}
\hline Name & & 1980 & 1985 & 1990 & 1995 & 2000 & 2005 & 2010 & 2015 \\
\hline \multirow{5}{*}{ CHP } & $\begin{array}{l}\text { Elec Gen } \\
\text { CHP }\end{array}$ & 258 & 58 & 619 & 20,521 & 26,863 & 57,457 & 94,012 & 100,598 \\
\hline & $\begin{array}{l}\text { Heat Gen } \\
\text { CHP }\end{array}$ & 659 & 166 & 1,498 & 48,408 & 61,784 & 125,858 & 205,931 & 201,196 \\
\hline & Total output & 917 & 224 & 2,117 & 68,929 & 88,647 & 183,315 & 299,943 & 301,794 \\
\hline & Efficiency & $70 \%$ & $70 \%$ & $70 \%$ & $70 \%$ & $70 \%$ & $70 \%$ & $70 \%$ & $70 \%$ \\
\hline & $\begin{array}{l}\text { Fuel } \\
\text { consumption }\end{array}$ & 1,310 & 320 & 3,025 & 98,470 & 126,638 & 261,878 & 428,490 & 431,134 \\
\hline
\end{tabular}

\subsubsection{Calculations of heat Bonus}

The heat bonus for the CHP has been shown in table 17

Table 13. Calculation of heat bonus (GWh)

\begin{tabular}{|c|c|c|c|c|c|c|c|c|c|}
\hline Name & & 1980 & 1985 & 1990 & 1995 & 2000 & 2005 & 2010 & 2015 \\
\hline \multirow{6}{*}{ CHP } & $\begin{array}{l}\text { Elec Gen } \\
\text { CHP }\end{array}$ & 258 & 58 & 619 & 20,521 & 26,863 & 57,457 & 94,012 & 100,598 \\
\hline & $\begin{array}{l}\text { Heat Gen } \\
\text { CHP }\end{array}$ & 659 & 166 & 1,498 & 48,408 & 61,784 & 125,858 & 205,931 & 201,196 \\
\hline & Total output & 917 & 224 & 2,117 & 68,929 & 88,647 & 183,315 & 299,943 & 301,794 \\
\hline & $\begin{array}{l}\text { Fuel } \\
\text { consumption }\end{array}$ & 1,310 & 320 & 3,025 & 98,470 & 126,638 & 261,878 & 428,490 & 431,134 \\
\hline & $\begin{array}{l}\text { PEF CHP } \\
\text { fuel }\end{array}$ & 1 & 1 & 1 & 1 & 1 & 1 & 1 & 1 \\
\hline & Heat Bonus & 941 & 199 & 2,140 & 69,154 & 88,262 & 179,796 & 294,187 & 287,422 \\
\hline
\end{tabular}




\subsubsection{Calculations of Primary energy factor of electricity}

The Final PEF of electricity generation by Eurostat Methodology has been shown in table 18.

Table 14. Final PEF of electricity generation by Eurostat Methodology

\begin{tabular}{|l|l|l|l|l|l|l|l|l|l|}
\hline & $\mathbf{1 9 8 0}$ & $\mathbf{1 9 8 5}$ & $\mathbf{1 9 9 0}$ & $\mathbf{1 9 9 5}$ & $\mathbf{2 0 0 0}$ & $\mathbf{2 0 0 5}$ & $\mathbf{2 0 1 0}$ & $\mathbf{2 0 1 5}$ \\
\hline RPED & 157,436 & 206,911 & 359,409 & 621,311 & 899,172 & $1,200,591$ & $1,543,169$ & $1,700,507$ \\
\hline $\begin{array}{l}\text { Heat } \\
\text { bonus }\end{array}$ & 941 & 199 & 2,140 & 69,154 & 88,262 & 179,796 & 294,187 & 287,422 \\
\hline $\begin{array}{l}\text { Net } \\
\text { electricity } \\
\text { demand }\end{array}$ & 65,075 & 85,048 & 137,441 & 260,026 & 373,135 & 513,765 & 707,890 & 772,117 \\
\hline
\end{tabular}

\subsubsection{Contributions to Primary energy factor}

The trend and the contribution of each source to the calculation of the PEF of electricity generation have been shown in the fig. 18 . 


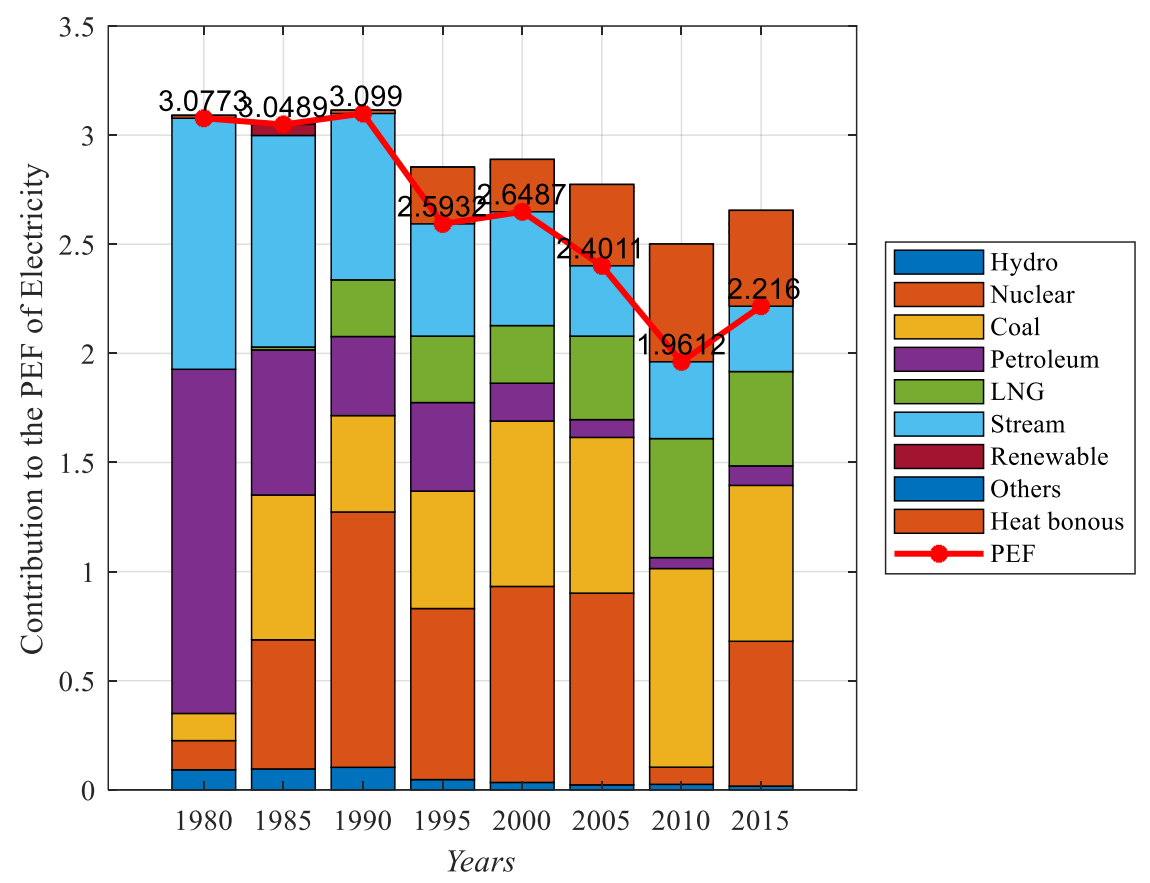

Figure 11. Calculation of Primary energy factor of electricity generation by Eurostat Methodology

As can be seen in the fig. 18 for the Eurostat methodology, the Primary energy factor of electricity increase from the period of 1980 to 1990. The value of the PEF was highest in 1990 and it was 3.099. After 1990, the value of PEF continue to decrease and it reaches at 1.80 in 2015. In the initial years, the Hydropower contributes more to the development of PEF. But in later years, the contribution of coal is more prominent.

\subsubsection{Calculations method 2 - Life Cycle Approach}

\subsubsection{Calculations of Raw Primary energy demand}

The RPED of the electricity generation for the Life Cycle approach has been shown in table 19.

Table 15. Calculations of RPED by Life cycle approach (GWh)

\begin{tabular}{|l|l|l|l|l|l|l|l|l|l|}
\hline Source & Factors & 1980 & 1985 & 1990 & 1995 & 2000 & 2005 & 2010 & 2015 \\
\hline & $\begin{array}{l}\text { Total } \\
\text { electricity } \\
\text { generation } \\
\begin{array}{l}\text { PE } \\
\text { demand }\end{array}\end{array}$ & 2,709 & 3,659 & 6,361 & 5,478 & 5,610 & 5,189 & 6,472 & 5,796 \\
\hline $\begin{array}{l}\text { Efficiency } \\
\text { PEF fuel }\end{array}$ & 162.3 & 219.5 & 381 & 328 & 336 & 311 & 388 & 347 \\
\hline Nuclear & $\begin{array}{l}\text { Total } \\
\text { electricity } \\
\text { generation }\end{array}$ & 2,897 & 16,745 & 52,887 & 67,029 & 108,964 & 146,779 & 148,596 & 164,762 \\
\hline
\end{tabular}




\begin{tabular}{|c|c|c|c|c|c|c|c|c|c|}
\hline & $\begin{array}{l}\text { PE } \\
\text { demand }\end{array}$ & 8,778 & 50,742 & 160,263 & 203,118 & 330,193 & 444,784 & 450,290 & 499,278 \\
\hline & Efficiency & \multicolumn{8}{|c|}{$33 \%$} \\
\hline & $\mathrm{PEF}_{\text {fuel }}$ & \multicolumn{8}{|c|}{1} \\
\hline \multirow[t]{4}{*}{ Coal } & $\begin{array}{l}\text { Total } \\
\text { electricity } \\
\text { generation }\end{array}$ & 2,530 & 17,639 & 19,961 & 48,813 & 97,538 & 133,658 & 197,916 & 213,803 \\
\hline & $\begin{array}{l}\text { PE } \\
\text { demand }\end{array}$ & 8,732 & 60,883 & 64,722 & 149,228 & 298,187 & 386,524 & 557,289 & 602,024 \\
\hline & Efficiency & $31 \%$ & $31 \%$ & $33 \%$ & $35 \%$ & $35 \%$ & $37 \%$ & $38 \%$ & $38 \%$ \\
\hline & PEF fuel & \multicolumn{8}{|c|}{1.07} \\
\hline \multirow[t]{4}{*}{ Petroleum } & $\begin{array}{l}\text { Total } \\
\text { electricity } \\
\text { generation }\end{array}$ & 32,071 & 19,964 & 18,856 & 42,045 & 26,142 & 17,733 & 12,878 & 31,616 \\
\hline & $\begin{array}{l}\text { PE } \\
\text { demand }\end{array}$ & 114,834 & 63,314 & 55,079 & 116,674 & 70,774 & 45,775 & 33,243 & 77,986 \\
\hline & Efficiency & $31 \%$ & $35 \%$ & $38 \%$ & $40 \%$ & $41 \%$ & $43 \%$ & $43 \%$ & $45 \%$ \\
\hline & PEF fuel & \multicolumn{8}{|c|}{1.11} \\
\hline \multirow[t]{4}{*}{ LNG } & $\begin{array}{l}\text { Total } \\
\text { electricity } \\
\text { generation }\end{array}$ & - & 250 & 9,604 & 21,296 & 28,146 & 58,118 & 96,734 & 100,783 \\
\hline & $\begin{array}{l}\text { PE } \\
\text { demand }\end{array}$ & - & 1,284 & 40,194 & 89,127 & 109,672 & 218,911 & 352,611 & 367,370 \\
\hline & Efficiency & $21 \%$ & $22 \%$ & $27 \%$ & $27 \%$ & $29 \%$ & $30 \%$ & $31 \%$ & $31 \%$ \\
\hline & $\mathrm{PEF}_{\text {fuel }}$ & \multicolumn{8}{|c|}{1.13} \\
\hline \multirow[t]{4}{*}{ Steam } & $\begin{array}{l}\text { Total } \\
\text { electricity } \\
\text { generation }\end{array}$ & 34,305 & 37,411 & 47,098 & 89,252 & 119,947 & 151,207 & 211,449 & 216,378 \\
\hline & $\begin{array}{l}\text { PE } \\
\text { demand }\end{array}$ & 2,401 & 2,618 & 3,296 & 6,247 & 8,396 & 10,584 & 14,801 & 15,146 \\
\hline & Efficiency & \multicolumn{8}{|c|}{$45 \%$} \\
\hline & $\mathrm{PEF}_{\text {fuel }}$ & & & & 0.07 & & & & \\
\hline \multirow[t]{5}{*}{ Renewable } & $\begin{array}{l}\text { Total } \\
\text { electricity } \\
\text { generation }\end{array}$ & 2492 & 2,031 & 797 & 1,051 & 2,130 & 3,961 & 6,064 & 12,839 \\
\hline & $\begin{array}{l}\text { PE } \\
\text { demand }\end{array}$ & 199 & 162.4 & 63.76 & 84.08 & 170 & 316 & 485 & 1027 \\
\hline & Efficiency & \multicolumn{8}{|c|}{$45 \%$} \\
\hline & $\mathrm{PEF}_{\text {fuel }}$ & \multicolumn{8}{|c|}{0.08} \\
\hline & $\begin{array}{l}\text { Raw } \\
\text { Primary } \\
\text { energy } \\
\text { demand }\end{array}$ & 167,010 & 179,222 & 323,998 & 565,964 & 821,631 & $1,110,368$ & $1,421,171$ & $1,584,082$ \\
\hline
\end{tabular}




\subsubsection{Calculations of heat Generation}

The heat generated from the CHP has been calculated in table 20. The self- consumption is assumed to be $8 \%$.

Table 16. Calculations of heat generation (GWh)

\begin{tabular}{|l|l|l|l|l|l|l|l|l|l|}
\hline Name & & $\mathbf{1 9 8 0}$ & $\mathbf{1 9 8 5}$ & $\mathbf{1 9 9 0}$ & $\mathbf{1 9 9 5}$ & $\mathbf{2 0 0 0}$ & $\mathbf{2 0 0 5}$ & $\mathbf{2 0 1 0}$ & $\mathbf{2 0 1 5}$ \\
\hline & $\begin{array}{l}\text { Electricity } \\
\text { generation }\end{array}$ & 258 & 58 & 619 & 20,521 & 26,863 & 57,457 & 94,012 & 100,598 \\
\hline & $\begin{array}{l}\text { Electricity/heat } \\
\mathbf{C H P}\end{array}$ & $36 \%$ & $38 \%$ & $38 \%$ & $39 \%$ & $40 \%$ & $42 \%$ & $42 \%$ & $46 \%$ \\
\hline
\end{tabular}

\subsubsection{Calculations of fuel consumption}

The calculation of fuel consumption for the CHP electricity and heat generation has been shown in table 21.

Table 17. Calculations of fuel consumption (GWh)

\begin{tabular}{|c|c|c|c|c|c|c|c|c|c|}
\hline Name & & 1980 & 1985 & 1990 & 1995 & 2000 & 2005 & 2010 & 2015 \\
\hline \multirow{5}{*}{ CHP } & $\begin{array}{l}\text { Elec Gen } \\
\text { CHP }\end{array}$ & 258 & 58 & 619 & 20,521 & 26,863 & 57,457 & 94,012 & 100,598 \\
\hline & $\begin{array}{l}\text { Heat Gen } \\
\text { CHP }\end{array}$ & 659 & 166 & 1,498 & 48,408 & 61,784 & 125,858 & 205,931 & 201,196 \\
\hline & Total output & 917 & 224 & 2,117 & 68,929 & 88,647 & 183,315 & 299,943 & 301,794 \\
\hline & Efficiency & $70 \%$ & $70 \%$ & $70 \%$ & $70 \%$ & $70 \%$ & $70 \%$ & $70 \%$ & $70 \%$ \\
\hline & $\begin{array}{l}\text { Fuel } \\
\text { consumption }\end{array}$ & 1310 & 320 & 3,025 & 98,470 & 126,638 & 261,878 & 428,490 & 431,134 \\
\hline
\end{tabular}

\subsubsection{Calculations of process efficiencies}

The life cycle approach uses the Finnish method for CHP evaluation. The efficiencies of electricity and heat generation for the CHP has been shown in table 22. 
Table 18. Calculations of efficiencies process

\begin{tabular}{|l|l|l|l|l|l|l|l|l|l|}
\hline Name & & $\mathbf{1 9 8 0}$ & $\mathbf{1 9 8 5}$ & $\mathbf{1 9 9 0}$ & $\mathbf{1 9 9 5}$ & $\mathbf{2 0 0 0}$ & $\mathbf{2 0 0 5}$ & $\mathbf{2 0 1 0}$ & $\mathbf{2 0 1 5}$ \\
\hline & Heat gen. & 659 & 166 & 1,498 & 48,408 & 61,784 & 125,858 & 205,931 & 201,196 \\
\hline & Fuel Cons. & 1310 & 320 & 3,025 & 98,470 & 126,638 & 261,878 & 428,490 & 431,134 \\
\hline & Efficiency & $50 \%$ & $51 \%$ & $49 \%$ & $49 \%$ & $48 \%$ & $48 \%$ & $48 \%$ & $46 \%$ \\
\hline
\end{tabular}

\subsubsection{Calculations of ratio of efficiencies compared to the alternative reference system}

Table 23 compared the ratio efficiencies compared to the alternative reference system

Table 19. Calculations of ratio efficiencies compared to the alternative reference system

\begin{tabular}{|c|c|c|c|c|c|c|c|c|}
\hline Indicator & 1980 & 1985 & 1990 & 1995 & 2000 & 2005 & 2010 & 2015 \\
\hline $\begin{array}{l}\text { CHP eff. } \\
\text { Elect. }\end{array}$ & $19 \%$ & $18 \%$ & $20 \%$ & $20 \%$ & $21 \%$ & $21 \%$ & $22 \%$ & $23 \%$ \\
\hline $\begin{array}{l}\text { Ref. eff. } \\
\text { Elec. }\end{array}$ & $40 \%$ & $40 \%$ & $40 \%$ & $40 \%$ & $40 \%$ & $40 \%$ & $40 \%$ & $40 \%$ \\
\hline Ratio eff. & $47.5 \%$ & $45 \%$ & $50 \%$ & $50 \%$ & $52 \%$ & $52 \%$ & $55 \%$ & $57 \%$ \\
\hline $\begin{array}{l}\text { CHP eff. } \\
\text { Heat }\end{array}$ & $50 \%$ & $51 \%$ & $49 \%$ & $49 \%$ & $48 \%$ & $48 \%$ & $48 \%$ & $46 \%$ \\
\hline $\begin{array}{l}\text { Ref. eff. } \\
\text { Heat }\end{array}$ & $90 \%$ & $90 \%$ & $90 \%$ & $90 \%$ & $90 \%$ & $90 \%$ & $90 \%$ & $90 \%$ \\
\hline Ratio eff. & $55 \%$ & $56 \%$ & $54 \%$ & $54 \%$ & $53 \%$ & $53 \%$ & $53 \%$ & $51 \%$ \\
\hline $\begin{array}{l}\text { Sum of } \\
\text { ratio eff. }\end{array}$ & 102.5 & $101 \%$ & $104 \%$ & $104 \%$ & $105 \%$ & $105 \%$ & $108 \%$ & $108 \%$ \\
\hline
\end{tabular}

\subsubsection{Calculations of the efficiency factor}

The efficiency factor for the life cycle approach has been shown in table 24. 
Table 20. Calculations of eiciency factor (GWh)

\begin{tabular}{|l|l|l|l|l|l|l|l|l|l|}
\hline CHP & Indicator & $\mathbf{1 9 8 0}$ & $\mathbf{1 9 8 5}$ & $\mathbf{1 9 9 0}$ & $\mathbf{1 9 9 5}$ & $\mathbf{2 0 0 0}$ & $\mathbf{2 0 0 5}$ & $\mathbf{2 0 1 0}$ & $\mathbf{2 0 1 5}$ \\
\hline & None & 1.00 & 1.00 & 1.00 & 1.00 & 1.00 & 1.00 & 1.00 & 1.00 \\
\hline $\begin{array}{l}\text { Sum of } \\
\text { ratio eff. }\end{array}$ & 1.02 & 1.01 & 1.04 & 1.04 & 1.05 & 1.05 & 1.08 & 1.08 \\
\hline $\begin{array}{l}\text { Efficiency } \\
\text { factor (1- } \\
\text { PEE) }\end{array}$ & $98 \%$ & $99 \%$ & $96 \%$ & $96 \%$ & $95 \%$ & $95 \%$ & $92 \%$ & $92 \%$ \\
\hline
\end{tabular}

\subsubsection{Calculations of heat bonus}

The calculations of heat bonus for the CHP system has been shown in table 25 .

Table 21. Calculations of heat Bonus (GWh)

\begin{tabular}{|c|c|c|c|c|c|c|c|c|c|}
\hline \multirow{6}{*}{ CHP } & Indicator & 1980 & 1985 & 1990 & 1995 & 2000 & 2005 & 2010 & 2015 \\
\hline & Fuel cons. & 1,310 & 3,200 & 3,025 & 98,470 & 126,638 & 261,878 & 428,490 & 431,134 \\
\hline & $\begin{array}{l}\text { Ratio reff. } \\
\text { Heat }\end{array}$ & $55 \%$ & $56 \%$ & $54 \%$ & $54 \%$ & $53 \%$ & $53 \%$ & $53 \%$ & $51 \%$ \\
\hline & (1-PEE) & $98 \%$ & $99 \%$ & $96 \%$ & $96 \%$ & $95 \%$ & $95 \%$ & $92 \%$ & $92 \%$ \\
\hline & PEF fuel & 1.07 & 1.06 & 1.04 & 1.03 & 1.02 & 1.02 & 1.01 & 1.01 \\
\hline & Heat bonus & 755 & 1,880 & 1,727 & 52,578 & 65,037 & 134,492 & 211,021 & 204,310 \\
\hline
\end{tabular}

\subsubsection{Calculations of primary energy factor of electricity}

Table 26 shows the final PEF of electricity generation by the life cycle approach.

Table 22. Calculation of PEF of electricity generation by Life Cycle Approach

\begin{tabular}{|l|l|l|l|l|l|l|l|l|}
\hline & $\mathbf{1 9 8 0}$ & $\mathbf{1 9 8 5}$ & $\mathbf{1 9 9 0}$ & $\mathbf{1 9 9 5}$ & $\mathbf{2 0 0 0}$ & $\mathbf{2 0 0 5}$ & $\mathbf{2 0 1 0}$ & $\mathbf{2 0 1 5}$ \\
\hline RPED & 167,012 & 179,222 & 323,998 & 565,964 & 821,631 & $1,110,368$ & $1,421,171$ & $1,584,082$ \\
\hline $\begin{array}{l}\text { Heat } \\
\text { bonus }\end{array}$ & 755 & 1,880 & 1,727 & 52,578 & 65,037 & 134,492 & 211,021 & 204,310 \\
\hline
\end{tabular}




\begin{tabular}{|l|l|l|l|l|l|l|l|l|}
\hline $\begin{array}{l}\text { Net } \\
\text { electricity } \\
\text { demand }\end{array}$ & 67,758 & 86,026 & 137,441 & 260,026 & 373,135 & 513,765 & 707,890 & 772,117 \\
\hline $\begin{array}{l}\text { Final } \\
\text { PEF }\end{array}$ & 2.10 & 2.13 & 2.39 & 2.13 & 2.18 & 2.10 & 1.62 & 1.93 \\
\hline
\end{tabular}

\subsubsection{Contribution to PEF}

The trend and the contribution of each source to the calculation of the PEF of electricity generation has been shown in the fig. 19.

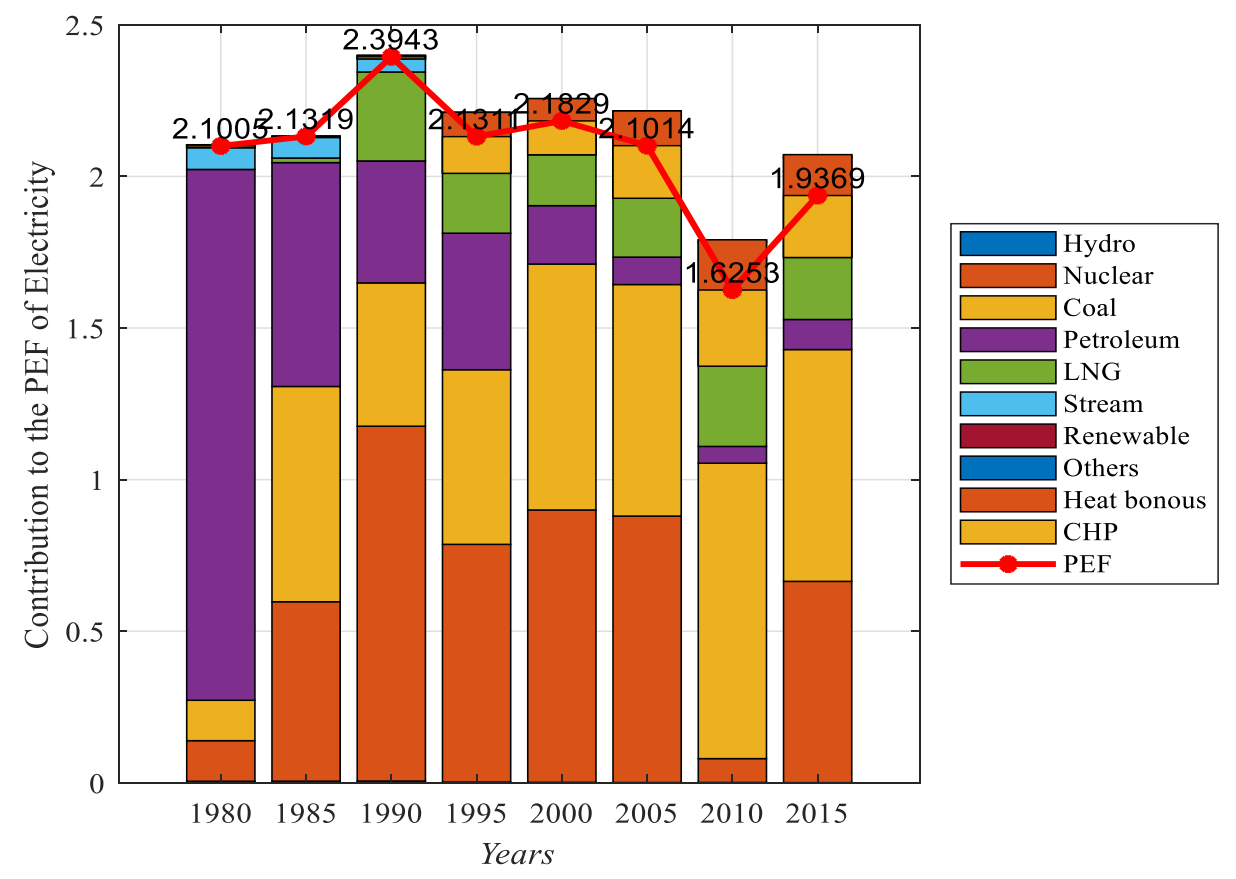

Figure 12. Calculation of PEF of electricity generation

For the LCA approach, As it can be seen in the fig. 19, the Primary energy factor of electricity increase from the period of 1980 to 1990. The value of the PEF was highest in 1990 and it was 2.39. After 1990, the value of PEF continue to decrease till 2010 and it reaches at 1.62 in 2015. In the initial years, the Hydropower contributes more to the development of PEF. But in the later years, the contribution of coal is more prominent. 


\subsubsection{Calculation method 3 - Modified Eurostat Methodology}

\subsubsection{Generation of heat calculation from Combined heat and power plant}

The heat generated from the CHP has been calculated in table 27. The self- consumption is assumed to be $8 \%$.

Table 23. Calculation of CHP heat generation (GWh)

\begin{tabular}{|l|l|l|l|l|l|l|l|l|l|}
\hline Name & & $\mathbf{1 9 8 0}$ & $\mathbf{1 9 8 5}$ & $\mathbf{1 9 9 0}$ & $\mathbf{1 9 9 5}$ & $\mathbf{2 0 0 0}$ & $\mathbf{2 0 0 5}$ & $\mathbf{2 0 1 0}$ & $\mathbf{2 0 1 5}$ \\
\hline & $\begin{array}{l}\text { Electricity } \\
\text { generation }\end{array}$ & 258 & 58 & 619 & 20521 & 26863 & 57457 & 94012 & 100598 \\
\hline & Electricity/heat & $36 \%$ & $38 \%$ & $38 \%$ & $39 \%$ & $40 \%$ & $42 \%$ & $42 \%$ & $46 \%$ \\
\hline \begin{tabular}{l} 
1-(Self-Cons) \\
\hline
\end{tabular} & $92 \%$ & $92 \%$ & $92 \%$ & $92 \%$ & $92 \%$ & $92 \%$ & $92 \%$ & $92 \%$ \\
\hline $\begin{array}{l}\text { Heat } \\
\text { generation }\end{array}$ & 659 & 166 & 1,498 & 48,408 & 61,784 & 125,858 & 205,931 & 201,196 \\
\hline
\end{tabular}

\subsubsection{Calculation of fuel consumption by CHP}

The calculation of fuel consumption for the CHP electricity and heat generation has been shown in table 28.

Table 24. Calculation of CHP Fuel consumption (GWh)

\begin{tabular}{|l|l|l|l|l|l|l|l|l|l|}
\hline Name & & $\mathbf{1 9 8 0}$ & $\mathbf{1 9 8 5}$ & $\mathbf{1 9 9 0}$ & $\mathbf{1 9 9 5}$ & $\mathbf{2 0 0 0}$ & $\mathbf{2 0 0 5}$ & $\mathbf{2 0 1 0}$ & $\mathbf{2 0 1 5}$ \\
\hline
\end{tabular}

\subsubsection{Calculation of process efficiencies}

The modified Eurostat methodology uses the Finnish method for the CHP evaluation. The efficiencies of electricity and heat generation for the CHP has been shown in table 29. 
Table 25. Calculations of CHP efficiencies of electricity and heat generation

\begin{tabular}{|l|l|l|l|l|l|l|l|l|l|}
\hline Name & & $\mathbf{1 9 8 0}$ & $\mathbf{1 9 8 5}$ & $\mathbf{1 9 9 0}$ & $\mathbf{1 9 9 5}$ & $\mathbf{2 0 0 0}$ & $\mathbf{2 0 0 5}$ & $\mathbf{2 0 1 0}$ & $\mathbf{2 0 1 5}$ \\
\hline & Heat gen. & 659 & 166 & 1,498 & 48,408 & 61,784 & 125,858 & 205,931 & 201,196 \\
\hline Fuel Cons. & 1310 & 320 & 3025 & 98470 & 126638 & 261878 & 428,490 & 431,134 \\
\hline $\mathbf{C H P}$ & Efficiency & $50 \%$ & $51 \%$ & $49 \%$ & $49 \%$ & $48 \%$ & $48 \%$ & $48 \%$ & $46 \%$ \\
\hline
\end{tabular}

\subsubsection{Calculations of ratio of efficiencies compared to the alternative reference system}

The table 30. Compared the ratio efficiencies compared to the alternative reference system.

Table 26. Calculations of ratio efficiencies compared to the alternative reference system

\begin{tabular}{|c|c|c|c|c|c|c|c|c|}
\hline Indicator & 1980 & 1985 & 1990 & 1995 & 2000 & 2005 & 2010 & 2015 \\
\hline $\begin{array}{l}\text { CHP eff. } \\
\text { Elect. }\end{array}$ & $19 \%$ & $18 \%$ & $20 \%$ & $20 \%$ & $21 \%$ & $21 \%$ & $22 \%$ & $23 \%$ \\
\hline $\begin{array}{l}\text { Ref. eff. } \\
\text { Elec. }\end{array}$ & $40 \%$ & $40 \%$ & $40 \%$ & $40 \%$ & $40 \%$ & $40 \%$ & $40 \%$ & $40 \%$ \\
\hline Ratio eff. & $47.5 \%$ & $45 \%$ & $50 \%$ & $50 \%$ & $52 \%$ & $52 \%$ & $55 \%$ & $57 \%$ \\
\hline $\begin{array}{l}\text { CHP eff. } \\
\text { Heat }\end{array}$ & $50 \%$ & $51 \%$ & $49 \%$ & $49 \%$ & $48 \%$ & $48 \%$ & $48 \%$ & $46 \%$ \\
\hline $\begin{array}{l}\text { Ref. eff. } \\
\text { Heat }\end{array}$ & $90 \%$ & $90 \%$ & $90 \%$ & $90 \%$ & $90 \%$ & $90 \%$ & $90 \%$ & $90 \%$ \\
\hline Ratio eff. & $55 \%$ & $56 \%$ & $54 \%$ & $54 \%$ & $53 \%$ & $53 \%$ & $53 \%$ & $51 \%$ \\
\hline $\begin{array}{l}\text { Sum of ratio } \\
\text { eff. }\end{array}$ & 102.5 & $101 \%$ & $104 \%$ & $104 \%$ & $105 \%$ & $105 \%$ & $108 \%$ & $108 \%$ \\
\hline
\end{tabular}

\subsubsection{Calculations of the efficiency factor}

The efficiency factor for the modified Eurostat methodology has been shown in table 31 
Table 27. Calculations of efficiency factor

\begin{tabular}{|c|c|c|c|c|c|c|c|c|c|}
\hline CHP & Indicator & 1980 & 1985 & 1990 & 1995 & 2000 & 2005 & 2010 & 2015 \\
\hline & None & 1.00 & 1.00 & 1.00 & 1.00 & 1.00 & 1.00 & 1.00 & 1.00 \\
\hline & $\begin{array}{l}\text { Sum of } \\
\text { ratio eff. }\end{array}$ & 1.02 & 1.01 & 1.04 & 1.04 & 1.05 & 1.05 & 1.08 & 1.08 \\
\hline & $\begin{array}{l}\text { Efficiency } \\
\text { factor (1- } \\
\text { PEE) }\end{array}$ & $98 \%$ & $99 \%$ & $96 \%$ & $96 \%$ & $95 \%$ & $95 \%$ & $92 \%$ & $92 \%$ \\
\hline
\end{tabular}

\subsubsection{Calculation of heat bonus}

The calculations of heat bonus for the CHP system has been shown in table 32 .

Table 28. Calculations of heat bonus

\begin{tabular}{|l|l|l|l|l|l|l|l|l|l|}
\hline Fuel & Indicator & $\mathbf{1 9 8 0}$ & $\mathbf{1 9 8 5}$ & $\mathbf{1 9 9 0}$ & $\mathbf{1 9 9 5}$ & $\mathbf{2 0 0 0}$ & $\mathbf{2 0 0 5}$ & $\mathbf{2 0 1 0}$ & $\mathbf{2 0 1 5}$ \\
\hline & Fuel cons. & 1310 & 3200 & 3025 & 98470 & 126638 & 261878 & 428490 & 431134 \\
\hline $\begin{array}{l}\text { Ratio reff. } \\
\text { Heat }\end{array}$ & $55 \%$ & $56 \%$ & $54 \%$ & $54 \%$ & $53 \%$ & $53 \%$ & $53 \%$ & $51 \%$ \\
\hline & (1-PEE) & $98 \%$ & $99 \%$ & $96 \%$ & $96 \%$ & $95 \%$ & $95 \%$ & $92 \%$ & $92 \%$ \\
\hline
\end{tabular}

\subsubsection{Calculation of primary energy factor of electricity}

Table 33 shows the final PEF of electricity generation by the life cycle approach.

Table 29. Calculations of Final PEF of electricity by modified Eurostat methodology

\begin{tabular}{|l|l|l|l|l|l|l|l|l|}
\hline & $\mathbf{1 9 8 0}$ & $\mathbf{1 9 8 5}$ & $\mathbf{1 9 9 0}$ & $\mathbf{1 9 9 5}$ & $\mathbf{2 0 0 0}$ & $\mathbf{2 0 0 5}$ & $\mathbf{2 0 1 0}$ & $\mathbf{2 0 1 5}$ \\
\hline RPED & 157,436 & 206,911 & 359,409 & 621,311 & 899,172 & $1,200,591$ & $1,543,169$ & $1,700,507$ \\
\hline $\begin{array}{l}\text { Heat } \\
\text { bonus }\end{array}$ & 706 & 1,774 & 1,568 & 51,046 & 63,762 & 131,855 & 208,931 & 202,288 \\
\hline
\end{tabular}




\begin{tabular}{|l|l|l|l|l|l|l|l|l|}
\hline $\begin{array}{l}\text { Net } \\
\text { electricity } \\
\text { demand }\end{array}$ & 67,758 & 86,026 & 137,441 & 260,026 & 373,135 & 513,765 & 707,890 & 772,117 \\
\hline Final PEF & 3.08 & 3.05 & 3.10 & 2.76 & 2.80 & 2.64 & 2.31 & 2.50 \\
\hline
\end{tabular}

\subsubsection{Contribution to PEF}

The trend and the contribution of each source to the calculation of the PEF of electricity generation have been shown in the fig. 20 .

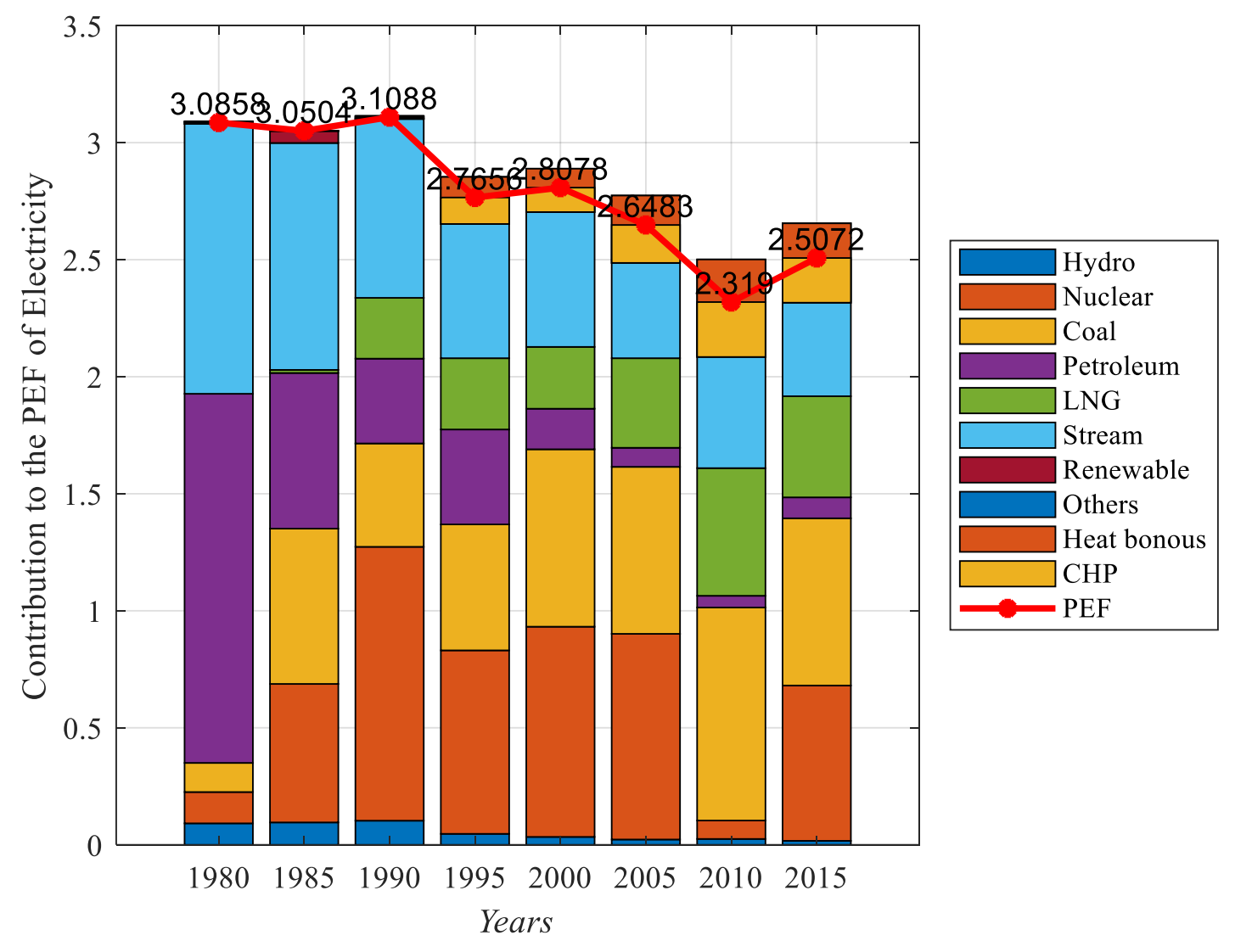

Figure 13. Contribution of energy sources to the development of PEF of electricity.

As can be seen in figure 20, for the Modified Eurostat methodology, the Primary energy factor of electricity increase from the period of 1980 to 1990. The value of the PEF was highest in 1990 and it was 3.10. After 1990, the value of PEF continues to decrease and it reaches at 2.50 in 2015. In the initial years, the Hydropower contributes more to the development of PEF. But in later years, the contribution of coal is more prominent. The basic difference between the Eurostat and Modified Eurostat Methodology that the Modified Eurostat methodology uses the Finnish method for the CHP analysis unless the IEA method in Eurostat methodology. 


\subsubsection{Calculation method 4 - Upper-end Method}

\subsubsection{Calculation of Raw Primary energy demand}

The RPED of the electricity generation for the Upper-end methodology has been shown in table 34 .

Table 30. Calculations of RPED by upper-end methodology

\begin{tabular}{|c|c|c|c|c|c|c|c|c|c|}
\hline Source & Factors & 1980 & 1985 & 1990 & 1995 & 2000 & 2005 & 2010 & 2015 \\
\hline \multirow[t]{4}{*}{ Hydro } & $\begin{array}{l}\text { Total } \\
\text { electricity } \\
\text { generation }\end{array}$ & 2,709 & 3,659 & 6,361 & 5,478 & 5,610 & 5,189 & 6,472 & 5,796 \\
\hline & $\begin{array}{l}\text { PE } \\
\text { demand }\end{array}$ & 2,709 & 3,659 & 6,361 & 5,478 & 5,610 & 5,189 & 6,472 & 5,796 \\
\hline & Efficiency & \multicolumn{8}{|c|}{$45 \%$} \\
\hline & PEF fuel & \multicolumn{8}{|c|}{1} \\
\hline \multirow[t]{4}{*}{ Nuclear } & $\begin{array}{l}\text { Total } \\
\text { electricity } \\
\text { generation }\end{array}$ & 2,897 & 16,745 & 52,887 & 67,029 & 108,964 & 146,779 & 148,596 & 164,762 \\
\hline & $\begin{array}{l}\text { PE } \\
\text { demand }\end{array}$ & 8,778 & 50,742 & 160,263 & 203,118 & 330,193 & 444,784 & 450,290 & 499,278 \\
\hline & Efficiency & \multicolumn{8}{|c|}{$33 \%$} \\
\hline & PEF fuel & \multicolumn{8}{|c|}{1} \\
\hline \multirow[t]{4}{*}{ Coal } & $\begin{array}{l}\text { Total } \\
\text { electricity } \\
\text { generation }\end{array}$ & 2,530 & 17,639 & 19,961 & 48,813 & 97,538 & 133,658 & 197,916 & 213,803 \\
\hline & $\begin{array}{l}\text { PE } \\
\text { demand }\end{array}$ & 9,059 & 63,159 & 71,473 & 154,806 & 309,334 & 400,974 & 578,123 & 624,529 \\
\hline & Efficiency & $31 \%$ & $31 \%$ & $33 \%$ & $35 \%$ & $35 \%$ & $37 \%$ & $38 \%$ & $38 \%$ \\
\hline & PEF fuel & \multicolumn{8}{|c|}{1.11} \\
\hline \multirow[t]{4}{*}{ Petroleum } & $\begin{array}{l}\text { Total } \\
\text { electricity } \\
\text { generation }\end{array}$ & 32,071 & 19,964 & 18,856 & 42,045 & 26,142 & 17,733 & 12,878 & 31,616 \\
\hline & $\begin{array}{l}\text { PE } \\
\text { demand }\end{array}$ & 114,834 & 63,314 & 55,079 & 116,674 & 70,774 & 45,775 & 33,243 & 77,986 \\
\hline & Efficiency & $31 \%$ & $35 \%$ & $38 \%$ & $40 \%$ & $41 \%$ & $43 \%$ & $43 \%$ & $45 \%$ \\
\hline & PEF fuel & \multicolumn{8}{|c|}{1.11} \\
\hline
\end{tabular}




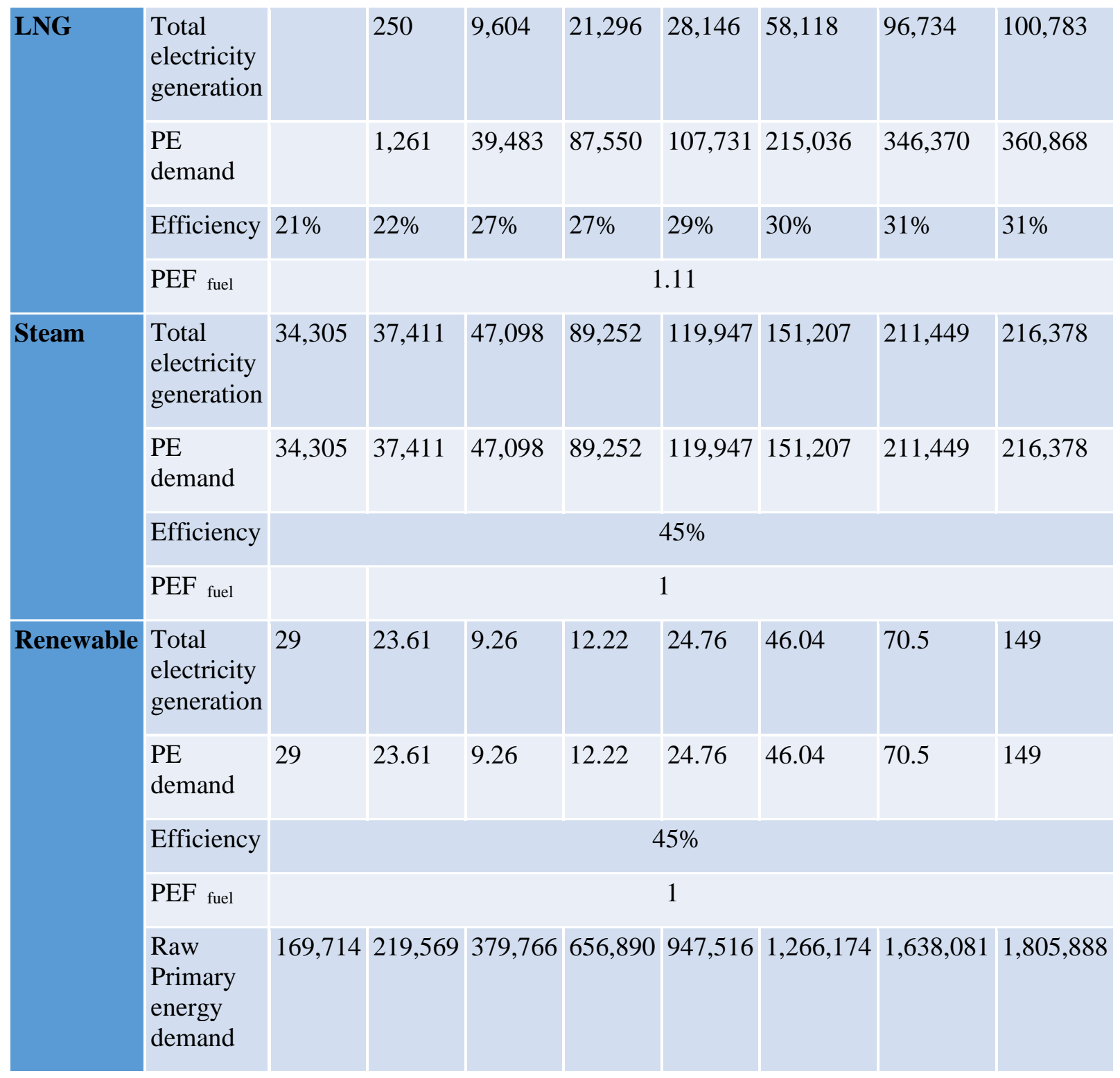

\subsubsection{Generation of heat calculation from Combined heat and power plant}

The heat generated from the CHP has been calculated in table 35 . The self- consumption is assumed to be $8 \%$,

Table 31. Calculation of heat generation

\begin{tabular}{|l|l|l|l|l|l|l|l|l|l|}
\hline Name & $\mathbf{1 9 8 0}$ & $\mathbf{1 9 8 5}$ & $\mathbf{1 9 9 0}$ & $\mathbf{1 9 9 5}$ & $\mathbf{2 0 0 0}$ & $\mathbf{2 0 0 5}$ & $\mathbf{2 0 1 0}$ & $\mathbf{2 0 1 5}$ \\
\hline $\begin{array}{l}\text { Electricity } \\
\text { generation }\end{array}$ & 258 & 58 & 619 & 20,521 & 26,863 & 57,457 & 94,012 & 100,598 \\
\hline \begin{tabular}{l} 
Electricity/heat \\
\hline
\end{tabular} & $36 \%$ & $38 \%$ & $38 \%$ & $39 \%$ & $40 \%$ & $42 \%$ & $42 \%$ & $46 \%$ \\
\hline
\end{tabular}




\begin{tabular}{|c|c|c|c|c|c|c|c|c|c|}
\hline \multirow[t]{2}{*}{ CHP } & 1-(Self-Cons) & $92 \%$ & $92 \%$ & $92 \%$ & $92 \%$ & $92 \%$ & $92 \%$ & $92 \%$ & $92 \%$ \\
\hline & $\begin{array}{l}\text { Heat } \\
\text { generation }\end{array}$ & 659 & 166 & 1,498 & 48,408 & 61,784 & 125,858 & 205,931 & 201,196 \\
\hline
\end{tabular}

\subsubsection{Calculation of fuel consumption}

The calculation of fuel consumption for the CHP electricity and heat generation has been shown in table 36.

Table 32. Calculation of fuel Consumption

\begin{tabular}{|l|l|l|l|l|l|l|l|l|l|}
\hline Name & & $\mathbf{1 9 8 0}$ & $\mathbf{1 9 8 5}$ & $\mathbf{1 9 9 0}$ & $\mathbf{1 9 9 5}$ & $\mathbf{2 0 0 0}$ & $\mathbf{2 0 0 5}$ & $\mathbf{2 0 1 0}$ & $\mathbf{2 0 1 5}$ \\
\hline
\end{tabular}

\subsubsection{Calculation of process efficiencies}

The upper-end methodology uses the Finnish method for the CHP evaluation. The efficiencies of electricity and heat generation for the CHP has been shown in table 37.

Table 33. Calculation of process efficiencies

\begin{tabular}{|l|l|l|l|l|l|l|l|l|l|}
\hline Name & & $\mathbf{1 9 8 0}$ & $\mathbf{1 9 8 5}$ & $\mathbf{1 9 9 0}$ & $\mathbf{1 9 9 5}$ & $\mathbf{2 0 0 0}$ & $\mathbf{2 0 0 5}$ & $\mathbf{2 0 1 0}$ & $\mathbf{2 0 1 5}$ \\
\hline & Heat gen. & 659 & 166 & 1,498 & 48,408 & 61,784 & 125,858 & 205,931 & 201,196 \\
\hline & Fuel Cons. & 1310 & 320 & 3,025 & 98,470 & 126,638 & 261,878 & 428,490 & 431,134 \\
\hline & Efficiency & $50 \%$ & $51 \%$ & $49 \%$ & $49 \%$ & $48 \%$ & $48 \%$ & $48 \%$ & $46 \%$ \\
\hline
\end{tabular}




\subsubsection{Calculations of ratio of efficiencies compared to the alternative reference system}

The table 38. Compared the ratio efficiencies compared to the alternative reference system

Table 34. Calculations of ratio efficiencies compared to the alternative reference system

\begin{tabular}{|c|c|c|c|c|c|c|c|c|c|}
\hline Name & Indicator & 1980 & 1985 & 1990 & 1995 & 2000 & 2005 & 2010 & 2015 \\
\hline & $\begin{array}{l}\text { CHP eff. } \\
\text { Elect. }\end{array}$ & $19 \%$ & $18 \%$ & $20 \%$ & $20 \%$ & $21 \%$ & $21 \%$ & $22 \%$ & $23 \%$ \\
\hline & $\begin{array}{l}\text { Ref. eff. } \\
\text { Elec. }\end{array}$ & $40 \%$ & $40 \%$ & $40 \%$ & $40 \%$ & $40 \%$ & $40 \%$ & $40 \%$ & $40 \%$ \\
\hline & Ratio eff. & $47.5 \%$ & $45 \%$ & $50 \%$ & $50 \%$ & $52 \%$ & $52 \%$ & $55 \%$ & $57 \%$ \\
\hline & $\begin{array}{l}\text { CHP eff. } \\
\text { Heat }\end{array}$ & $50 \%$ & $51 \%$ & $49 \%$ & $49 \%$ & $48 \%$ & $48 \%$ & $48 \%$ & $46 \%$ \\
\hline & $\begin{array}{l}\text { Ref. eff. } \\
\text { Heat }\end{array}$ & $90 \%$ & $90 \%$ & $90 \%$ & $90 \%$ & $90 \%$ & $90 \%$ & $90 \%$ & $90 \%$ \\
\hline & Ratio eff. & $55 \%$ & $56 \%$ & $54 \%$ & $54 \%$ & $53 \%$ & $53 \%$ & $53 \%$ & $51 \%$ \\
\hline & $\begin{array}{l}\text { Sum of ratio } \\
\text { eff. }\end{array}$ & 102.5 & $101 \%$ & $104 \%$ & $104 \%$ & $105 \%$ & $105 \%$ & $108 \%$ & $108 \%$ \\
\hline
\end{tabular}

\subsubsection{Calculations of the efficiency factor}

The efficiency factor for the life cycle approach has been shown in table 39.

Table 35. Calculations of efficiency factor

\begin{tabular}{|l|l|l|l|l|l|l|l|l|l|}
\hline Name & Indicator & $\mathbf{1 9 8 0}$ & $\mathbf{1 9 8 5}$ & $\mathbf{1 9 9 0}$ & $\mathbf{1 9 9 5}$ & $\mathbf{2 0 0 0}$ & $\mathbf{2 0 0 5}$ & $\mathbf{2 0 1 0}$ & $\mathbf{2 0 1 5}$ \\
\hline & None & 1.00 & 1.00 & 1.00 & 1.00 & 1.00 & 1.00 & 1.00 & 1.00 \\
\hline $\begin{array}{l}\text { Sum of } \\
\text { ratio eff. }\end{array}$ & 1.02 & 1.01 & 1.04 & 1.04 & 1.05 & 1.05 & 1.08 & 1.08 \\
\hline & $\begin{array}{l}\text { Efficiency } \\
\text { factor (1- } \\
\text { PEE) }\end{array}$ & $98 \%$ & $99 \%$ & $96 \%$ & $96 \%$ & $95 \%$ & $95 \%$ & $92 \%$ & $92 \%$ \\
\hline
\end{tabular}




\subsubsection{Calculation of heat bonus}

The calculations of heat bonus for the CHP system has been shown in table 40 .

Table 36. Calculations of heat bonus

\begin{tabular}{|c|c|c|c|c|c|c|c|c|c|}
\hline Fuel & Indicator & 1980 & 1985 & 1990 & 1995 & 2000 & 2005 & 2010 & 2015 \\
\hline \multirow{5}{*}{ CHP } & Fuel cons. & 1,310 & 3,200 & 3,025 & 98,470 & 126,638 & 261,878 & 428,490 & 431,134 \\
\hline & $\begin{array}{l}\text { Ratio reff. } \\
\text { Heat }\end{array}$ & $55 \%$ & $56 \%$ & $54 \%$ & $54 \%$ & $53 \%$ & $53 \%$ & $53 \%$ & $51 \%$ \\
\hline & (1-PEE) & $98 \%$ & $99 \%$ & $96 \%$ & $96 \%$ & $95 \%$ & $95 \%$ & $92 \%$ & $92 \%$ \\
\hline & PEF fuel & 1.10 & 1.10 & 1.09 & 1.09 & 1.09 & 1.08 & 1.07 & 1.07 \\
\hline & $\begin{array}{l}\text { Heat } \\
\text { bonus }\end{array}$ & 778 & 1,951 & 1,710 & 55,641 & 69,500 & 142,404 & 223,557 & 216,448 \\
\hline
\end{tabular}

\subsubsection{Calculation of primary energy factor of electricity}

Table 41 shows the final PEF of electricity generation by upper-end methodology.

Table 37. Calculations of final PEF of electricity

\begin{tabular}{|l|l|l|l|l|l|l|l|l|}
\hline & $\mathbf{1 9 8 0}$ & $\mathbf{1 9 8 5}$ & $\mathbf{1 9 9 0}$ & $\mathbf{1 9 9 5}$ & $\mathbf{2 0 0 0}$ & $\mathbf{2 0 0 5}$ & $\mathbf{2 0 1 0}$ & $\mathbf{2 0 1 5}$ \\
\hline RPED & 169,714 & 219,569 & 379,766 & 656,890 & 947,516 & $1,266,174$ & $1,638,081$ & $1,805,888$ \\
\hline $\begin{array}{l}\text { Heat } \\
\text { bonus }\end{array}$ & 778 & 1,951 & 1,710 & 5,5641 & 69,500 & 142,404 & 223,557 & 216,448 \\
\hline $\begin{array}{l}\text { Net } \\
\text { electricity } \\
\text { demand }\end{array}$ & 67,758 & 86,026 & 137,441 & 260,026 & 373,135 & 513,765 & 707,890 & 772,117 \\
\hline $\begin{array}{l}\text { Final } \\
\text { PEF }\end{array}$ & 3.26 & 3.17 & 3.21 & 2.89 & 2.92 & 2.77 & 2.48 & 2.64 \\
\hline
\end{tabular}




\subsubsection{Contribution to PEF}

The trend and the contribution of each source to the calculation of the PEF of electricity generation has been shown in the fig. 21 .

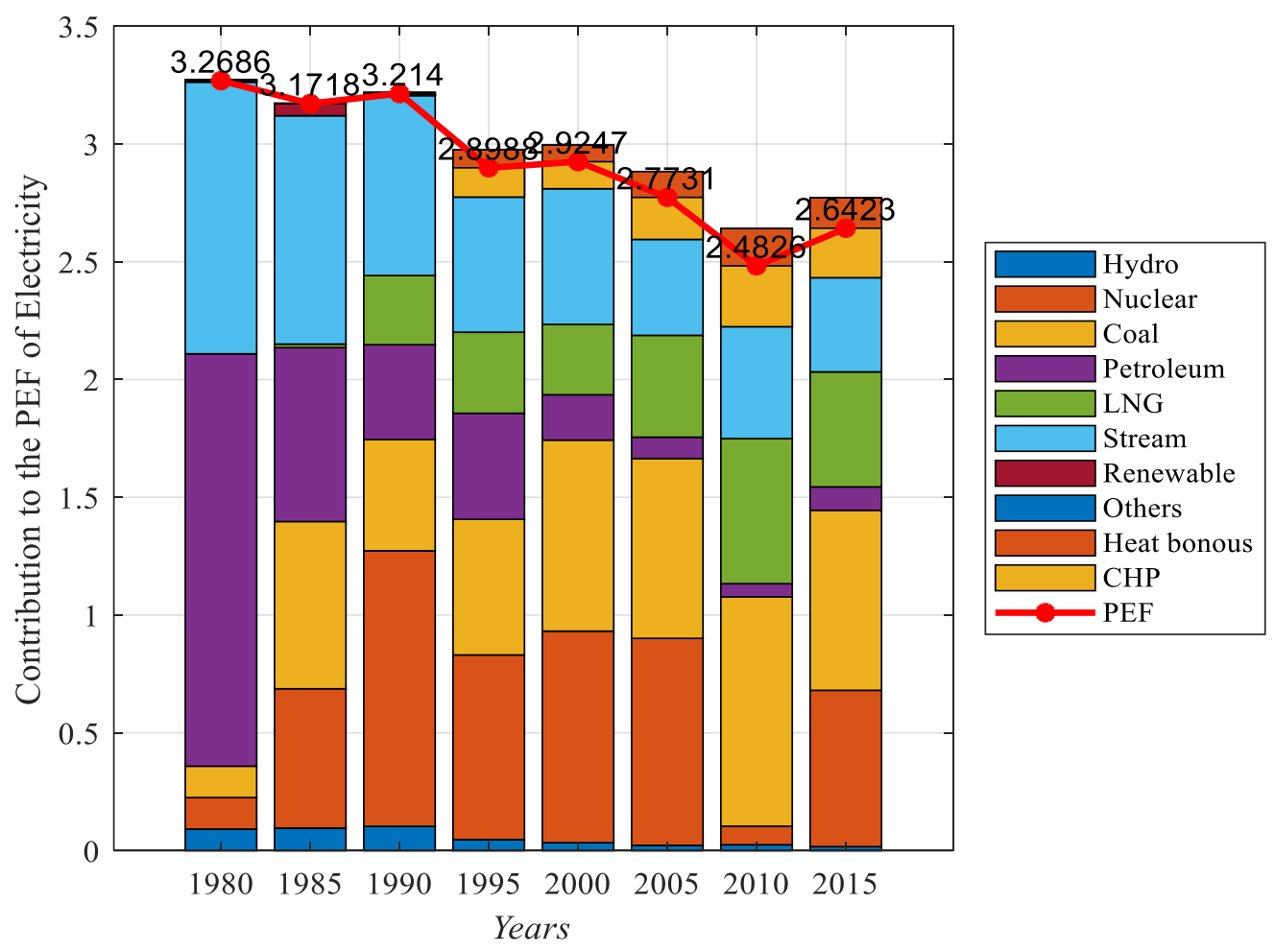

Figure 14. Calculations of PEF of electricity by the upper-end method

As can be seen in figure 21, for the upper-end methodology, the Primary energy factor of electricity increase from the period of 1980 to 1990 . The value of the PEF was highest in 1990 and it was 3.21. After 1990, the value of PEF continues to decrease and it reaches 2.48 in 2010 and slightly increase in 2015 to 2.64. In the initial years, the Hydropower contributed more to the development of PEF. But in the later years, the contribution of coal was more prominent.

\subsubsection{Comparison of all four methods}

The Comparison of all the four methods has been shown in Figure 22 


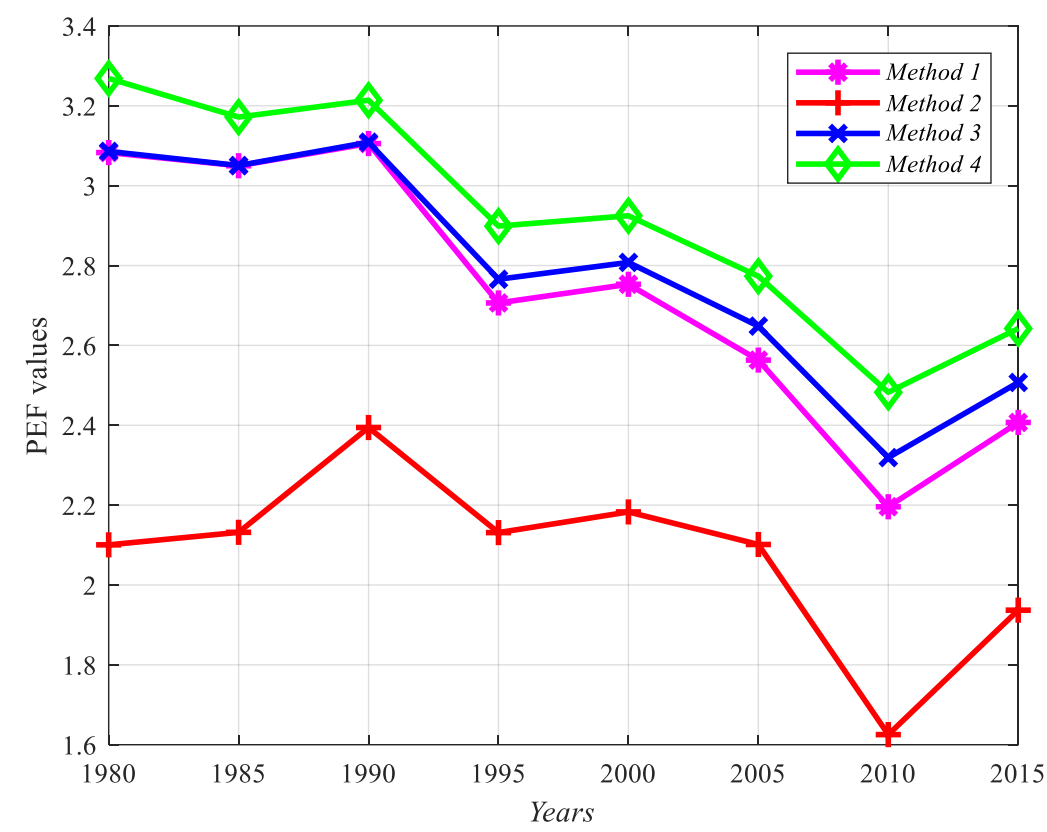

Figure 15. Comparison of methods for the development of PEF of electricity

As can be seen in Figure 22, that the LCA methodology has the lowest value trend of PEF of electricity. The maximum value of PEF in case of LCA methodology was 2.36. The Upper-end method has the highest value trend of PEF. For the non-renewable sources, it considers the LCA methodology and taking into account the entire supply chain. In all the four methods, the PEF values of electricity have been decreasing and increase slightly at the end.

\subsubsection{Future Trends of PEF}

The future trend of the PEF of electricity generation has been shown in figure 23 . 


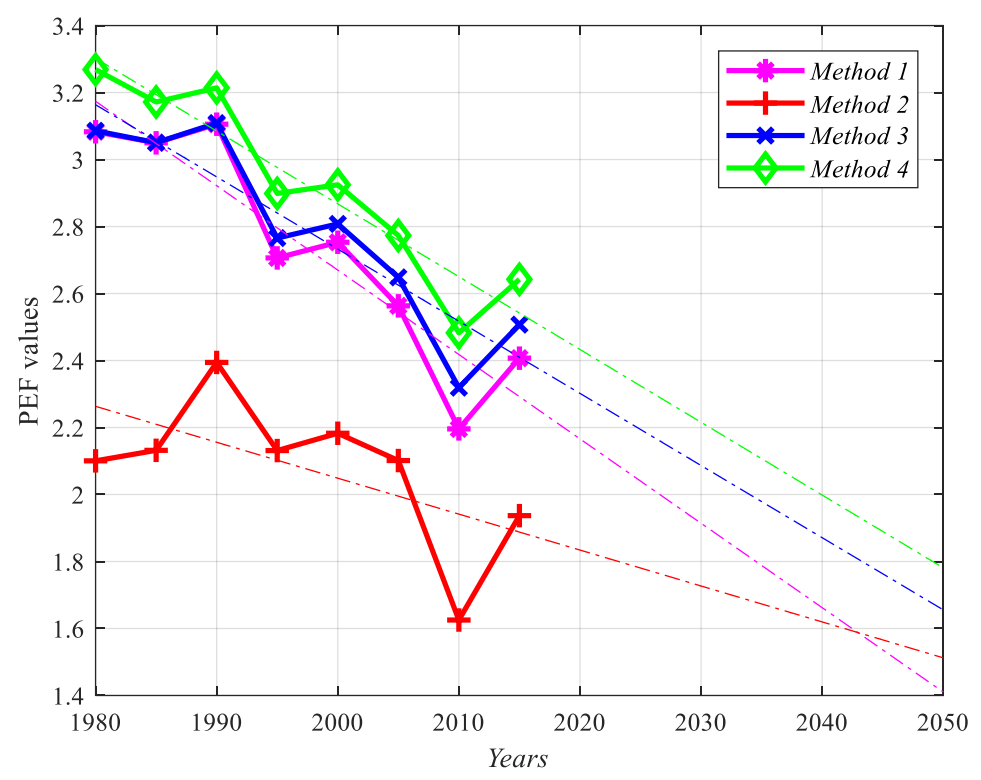

Figure 16. Future Trend of PEF of electricity

For all the methods, the PEF of electricity is going to decrease. The PEF of electricity generation in 2030 will be around 1.90 and 2.10 according to Eurostat and modified Eurostat methodology. For the LCA and the upper end, the PEF of electricity generation will be around 1.70 and 2.20 respectively.

For the year 2040, the PEF of electricity generation will be around 1.65 and 1.90 according to Eurostat and modified Eurostat methodology. For the LCA and the upper-end methodology, the PEF of electricity generation will be around 1.60 and 2.00 respectively.

For the year 2050, the PEF of electricity generation will be around 1.40 and 1.60 according to Eurostat and modified Eurostat methodology. For the LCA and the upper-end methodology, the PEF of electricity generation will be around 1.50 and 1.80 respectivel23

\subsubsection{Recommended PEF values of electricity generations for policymaking}

The fig. 24 shows the recommended values of PEF of electricity generation in South Korea for Policy making. 


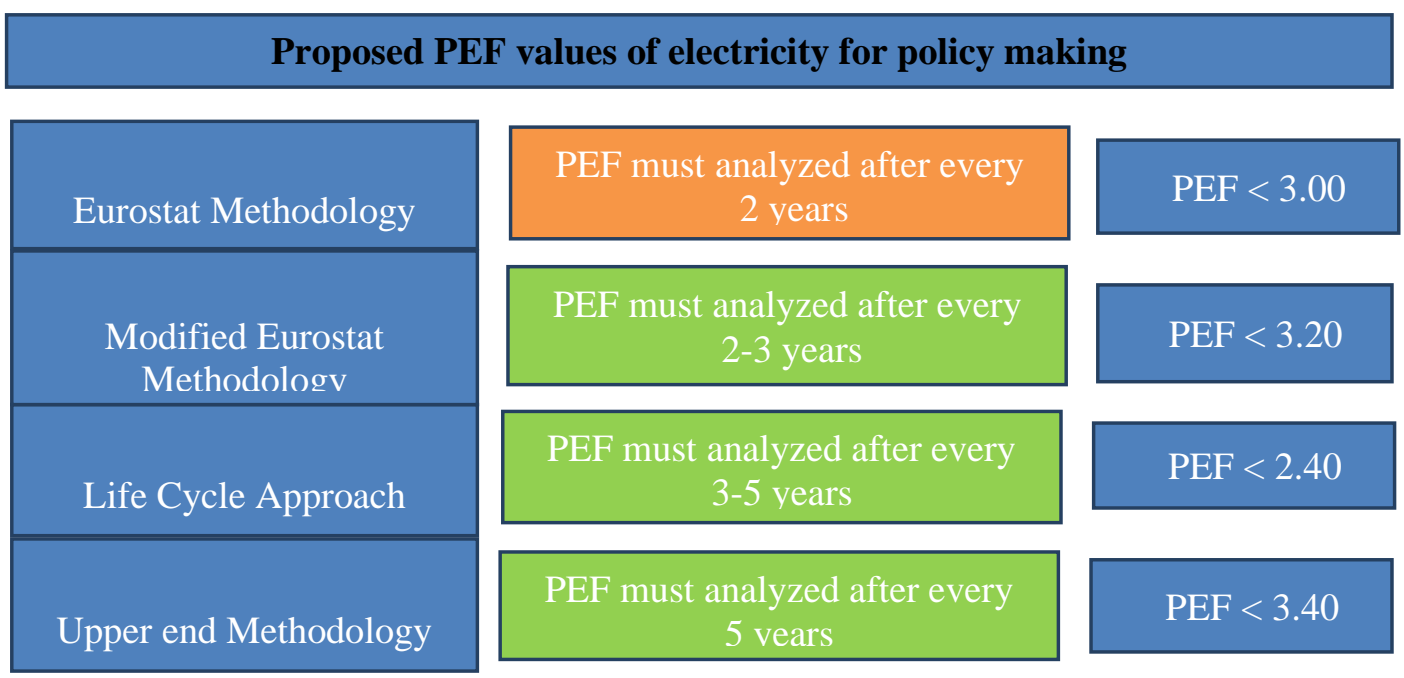

Figure 17. Optimized values of PEF of electricity generations

For the Eurostat methodology, the recommended value of PEF must be less than 3 and it must be analyzed every 2 years. For the Modified Eurostat methodology, the recommended value of PEF must be less than 3.20 and it must be analyzed with 2-3 years. The PEF of electricity calculated through the Life Cycle approach must be less than 2.40 and it must be analyzed with 3-5 years. The upper-end method provides the highest value of PEF and it must be analyzed after every 5 years. Its value must be less than 3.40. In the policymaking, it must be confirmed that any energy source imported to generate electricity in South Korea does not raise the threshold value of the PEF of electricity recommended for each method.

\section{Conclusion}

The PEF of electricity were calculated using 4 different methodologies

- Eurostat Methodologies

- Life cycle approach

- Modified Eurostat Methodologies

- Upper-end method

The Eurostat methodology considers the conversion and transmission portion only and calculates the total PEF, whereas the Life cycle method considers the entire supply chain and calculate only the nonrenewable portion of PEF. The basic difference between Eurostat and modified Eurostat methodology is the method of evaluating electricity generation from the CHP plant. The Eurostat methodology uses the IEA method and the Modified Eurostat methodology use the Finnish method to evaluate the electricity generation from CHP. The upper-end method sets the upper limit of calculating PEF and calculate total PEF. In all the four methods, the PEF of electricity shows the decreasing trend. The upper-end method showed the highest values trend of PEF and the lowest values trend was calculated using the Life cycle approach. It has been extrapolated that in 2050, the PEF values of electricity would be 1.4 and 1.6 according to Eurostat and modified Eurostat methodology respectively. According to the Life cycle and upper-end methodology, the PEF values of electricity will be 1.5 and 1.8 respectively.

\section{References}

1. "BP Statistical Review of World Energy 2018". $2^{\text {nd }}$ Edition

2. United Nations Development (2016). "World population prospects". United Nation Program

3. Global Footprint Network (2016) "World footprint.". Global Footprint Network. 
4. Will, Steffen.; Katherine, Richardson.; Johan, Rockström.(2015), “Planetary boundaries: Guiding human development on a changing planet". American Association for the Advancement of Science, vol. 347, (6223).

5. Independent statistics and analysis of US Energy administration (2018) "Country Analysis Brief: South Korea". US Energy Administration.

6. Newsbase, AsianOil, "South Korea plans LNG import liberalization in 2025" (2016),

7. S\&P Global Platts, "S Korea to allow buyers to bypass Kogas, import LNG directly from 2025", (2016).

8. Korea energy info (2017)". Korea Energy economics institute.

9. 11.M. K. Dixit, J. L. Fernandez-Sol, S. Lavy and C. H. Culp, Renewable Sustainable Energy Rev., 2012,16(6), 3730-3743

10. Energy Star, Energy Star Portfolio Manager, 2013.

11. Deru, M.; and Torcellini, P. “ Technical Report: Source energy and emission factors for energy use in buildings", National Renewable Energy Laboratory, Golden, CO, USA, 2007.

12. Dixit, M. K..; Fernandez, J. L.; Lavy, S.; Culp, C. H.. (2014) "Calculating Energy factor and carbon emission factor for the united states energy sector". Royal Society of chemistry, 42(8), $1238-1247$.

13. Dodoo, Ambrose, (2011) "Life cycle primary energy use and carbon emission of an eight-story wood-framed apartment building", Energy and Buildings, 42 (2). 230-242.

14. Gretchen, C.; Daily, Paul R.; Ehrlich. Population. (1992), 'Sustainability, and Earth's Carrying Capacity: A framework for estimating population sizes and lifestyles that could be sustained without undermining future generations", American Institute of Biological Sciences, 42(10), 761 771.

15. S. Øvergaard and S. "Norway, Statistics" (2008) Norway, Oslo, 2008.

16. Thormark, C. (2002). A low energy building in a life cycle - its embodied energy, energy need for operation and recycling potential. Building and Environment, 37(4), 429-435.

17. Fay, G. Treloar, U. Iyer-Raniga (2000), Life-cycle energy analysis of buildings: a case study, Building Research \& Information 28 (1) (2000) 31-41.

18. Marcogaz, UTIL-10-09, Technical Association of the European

19. C. Pout, STP11/CO204, "Building Research Establishment(BRE)," UK, 2009

20. D. V. Dijk, "TNO Built Environment and Geoscience" (2008). Netherlands,

21. European Committee for standardization (2014)," Annual report: Work Programme ".European Committee for standardization

22. E. Molenbroek, E. Stricker and T. Boermans," Ecofys report,2011”.

23. Anke; Esser, Frank; Sensfuss, "Final report Evaluation of primary energy factor calculation options for electricity", Technalia, Fraunhofer-Institut für System- und Innovationsforschung (ISI) (2016) 